\title{
Provenance of the Miocene Alto Tunuyán Basin (3340'S, Argentina) and its implications for the evolution of the Andean Range: Insights from petrography and U-Pb LA-ICPMS zircon ages
}

\author{
Hernán Porras a,d, Luisa Pinto ${ }^{\mathrm{a}, *}$, Maisa Tunik ${ }^{\mathrm{b}}$, Laura Giambiagi ${ }^{\mathrm{c}}$, Katja Deckart ${ }^{\mathrm{a}, \mathrm{e}}$ \\ a Departamento de Geología, Facultad de Ciencias Físicas y Matemáticas, Universidad de Chile, Plaza Ercilla 803, Casilla 13518, Correo 21, Santiago, Chile \\ b Instituto de Investigación en Paleobiología y Geología, Universidad Nacional de Río Negro, CONICET, Isidro Lobo y Belgrano, 8332 General Roca, Río Negro, Argentina \\ c CONICET - IANIGLA, CCT Mendoza, CC 330, 5500 Mendoza, Argentina \\ ' Observatorio Vulcanológico y Sismológico de Costa Rica, Universidad Nacional, Heredia, Costa Rica \\ e Advanced Mining Technology Center (AMTC), Facultad de Ciencias Físicas y Matemáticas, Universidad de Chile, Av. Tupper 2007, Santiago, Chile
}

\section{A R T I C L E I N F O}

\section{Article history:}

Received 24 January 2016

Received in revised form 28 September 2016

Accepted 30 September 2016

Available online 1 October 2016

\section{Keywords:}

Provenance

Alto Tunuyán Basin

Andes

$\mathrm{U}-\mathrm{Pb}$ ages

Petrography

\begin{abstract}
A B S T R A C T
The Alto Tunuyán Foreland Basin in western Argentina is located immediately south of the flat-slab segment of the Central Andes and its evolution is directly related to the propagation of structures to the east. Petrographic and geochronologic studies have been performed to determine the provenance of syntectonic sediments in the basin in order to establish their relationship to the Andean orogenic activity. The analysed detrital and igneous zircons in contrast with previous data, allow us to restrict the basin age between ca. 15 and 6 Ma. Sandstones record two main contributions, one from andesitic volcanic rocks and the other from an acidic igneous source, the first probably corresponding to Miocene volcanic rocks from the Principal Cordillera (Farellones Formation) and the second to Permo-Triassic, acidic, igneous rocks from the Frontal Cordillera (Choiyoi Magmatic Province, CMP). Two secondary sources have been recorded, sedimentary and metamorphic; the first one is represented by Mesozoic rocks in the Principal Cordillera and the second by the Proterozoic/early Carboniferous Guarguaráz Complex (GC) in the Frontal Cordillera, respectively. Sandstones from the lower basin deposits (15-11 Ma) register supply pulses from the Farellones Formation reflecting the unroofing of the Principal Cordillera by uplift pulses during the middle Miocene. Sandstones from the upper basin deposits (ca. 11-9 Ma) record an increase in material derived from the CMP, reflecting important uplift of the Frontal Cordillera. A thick, ca. 9 Ma old ignimbrite within the basin indicates an eruption in the Frontal Cordillera. Detrital zircons from the CMP have been detected also in the lower basin deposits, suggesting either recycling of Mesozoic deposits containing CMP zircons or an early paleorelief of the Frontal Cordillera. The good correlation between the age of the detrital zircons of the CMP and the GC in the lower basin deposits supports recycling of Mesozoic sedimentary deposits.
\end{abstract}

(c) 2016 Elsevier B.V. All rights reserved.

\section{Introduction}

The Andean Cordillera is a continuous orogenic belt located along the western margin of South America, formed by the subduction of the Nazca Oceanic Slab underneath the South American Continental Plate (Fig. 1a) (Dewey and Bird, 1970). This orogenic belt varies significantly and systematically along strike $(\sim 9000 \mathrm{~km})$ in topography, morphology, tectonics, basin distribution, volcanism, subduction geometry, crustal thickness, lithospheric structure, and geological evolution (e.g., Gansser, 1973; Baranzangi and Isacks, 1976; Jordan et al., 1983; Isacks, 1988; Cahill and Isacks, 1992; Gutscher, 2002; Tassara and Yáñez,

\footnotetext{
* Corresponding author.

E-mail address: Ipinto@ing.uchile.cl (L. Pinto).
}

2003; Stern, 2004). Subduction in the Central Andes along the Chilean margin $\left(3^{\circ}-47^{\circ} \mathrm{S}\right.$, Fig. $\left.1 \mathrm{a}, \mathrm{c}\right)$ is generally considered to be highly coupled (e.g., Cloos and Shreve, 1996). Two flat-slab subduction zones are recognized in this Andean sector, one in Peru $\left(2^{\circ}-15^{\circ} \mathrm{S}\right)$ and the other in Chile $\left(27^{\circ}-33^{\circ} \mathrm{S}\right)$. South of the Chilean flat-slab, the slab is characterized by normal subduction (e.g., Baranzangi and Isacks, 1976; Cahill and Isacks, 1992; Gregory-Wodzicki, 2000; Gutscher, 2002; Alvarado et al., 2007). Along this segment of normal subduction, at $33^{\circ}-34^{\circ} \mathrm{S}$, the Andean morphostructural units are, from west to east: the Coastal Cordillera, the Central Depression, the Principal Cordillera, the Frontal Cordillera and the Foreland (Fig. 1b). In the Principal Cordillera, the Abanico Extensional Basin developed between ca. 37 and 23 Ma (e.g., MuñozSáez et al., 2014 and references therein). Between 23 and 17 Ma the basin was partially inverted, however volcanic activity continued uninterruptedly generating the thick Farellones Formation that covers the 
Abanico deposits (e.g., Charrier et al., 2002; Fock et al., 2006; Muñoz-Sáez et al., 2014). During the middle to late Miocene (ca. 18 to $8.5 \mathrm{Ma}$ ), the deformation front migrated gradually to the east, generating the Aconcagua Fold-and-Thrust Belt (AFTB, Fig. 1c) (e.g., Giambiagi, 1999, 2000). We associate the AFTB with an eastward shortcut structure rooted in the eastern Abanico Basin bounding fault, the El Fierro Fault (Muñoz-Sáez et al., 2014), which is connected to deep structures in the basement. During this stage, two synorogenic basins developed at these latitudes: the Alto Tunuyán and Cacheuta Basins (Fig. 1b) (e.g., Giambiagi et al., 2003b), the former progressing from a foreland to a piggyback basin.

The Alto Tunuyán Basin, associated with the development of the AFTB (Fig. 2), was formed in the Argentinean Miocene foreland region and is presently located between the Principal Cordillera and the Frontal Cordillera forming the western part of a broken foreland (Fig. 1a, b) (e.g., Yrigoyen, 1993; Giambiagi, 2000; Giambiagi et al., 2003a, b).

Previous studies (e.g., Darwin, 1846; Giambiagi, 1999, 2000; Ramos et al., 2000; Giambiagi et al., 2003b) proposed a foreland to piggyback basin evolution based on the composition and abundance of clasts in the synorogenic conglomerates. The evolution model proposed by Giambiagi et al. (2003b) indicates that as the Alto Tunuyán Basin developed, it received a contribution of andesitic volcanics (until at least $15 \mathrm{Ma}$ ) followed by a strong supply from the Mesozoic successions (15-10.9 Ma), both sources located in the Chilean Principal Cordillera. Although the authors suggested that in its early stages, the basin could have been associated with the existence of a forebulge east of the present location of the Frontal Cordillera, they did not present evidence for this relief. With the eastward shift of the deformation front towards the foreland, the basement block composing the present-day Frontal Cordillera was uplifted by a deeply rooted east-vergent fault system located at its eastern side. This is evidenced by the presence in the Alto Tunuyán Basin of abundant fragments of pink granites and metamorphic rock fragments that originated to the east in the Frontal Cordillera. These authors did not specify which of the two volcanic Cenozoic units known in the Chilean Principal Cordillera, the Abanico and the Farellones Formations, supplied the andesitic material. Furthermore, the evolutionary stages for the Alto Tunuyán Basin were based on correlations without chronological data from the basin deposits. For this reason, the main goal of our research is to provide additional petrographic and geochronologic information from the basin infill to better constrain the evolution on the eastern Andean versant, at $\sim 33^{\circ} 40^{\prime} \mathrm{S}$.

Generally, modern provenance analytical methodology integrates petrography, geochemistry, heavy minerals and zircon geochronology in order to determine the source rocks of detrital basin sediments (e.g., Dickinson, 1970; Bhatia, 1983; Roser and Korsh, 1986, 1988; Pettijohn et al., 1987; Krawinkel et al., 1999; Lee, 2002; Weltje and von Eynatten, 2004; Pinto et al., 2004, 2007; Kutterolf et al., 2008; Alarcón and Pinto, 2015; Oghenekomea et al., 2016). These techniques also enable discussion on the tectonically uplifted blocks as source regions of the syntectonic deposits (e.g., Dickinson, 1970; Pinto et al., 2004; Weltje and Von Eynatten, 2004; Alarcón and Pinto, 2015). Furthermore, studies of detrital zircon geochronology have shown that these minerals are excellent tracers in resolving the provenance and recycling of the zircon-containing units in the Andes (e.g., Bahlburg et al., 2009; Ramos, 2009; Naipauer and García Morabito, 2012, Naipauer et al., 2015).

This paper adds new petrologic and geochronologic data to back up a detailed discussion of the provenance of the detrital sedimentary rocks belonging to the Alto Tunuyán Basin $\left(\sim 33^{\circ} 40^{\prime} S\right)$. The data help to chronologically constrain the propagation of the deformation front from the Chilean Principal Cordillera towards the east up to the Frontal Cordillera and to establish more precisely the age of the Alto Tunuyán Basin. The methodologies include sedimentary petrography and U-Pb LA-ICPMS dating of detrital zircons. These results enable us to discuss the evolution of uplifted blocks through their erosion and sediment supply to the Alto Tunuyán Basin during the Andean Orogeny.

\section{The Aconcagua Fold-and-Thrust Belt (AFTB) and the syntectonic Alto Tunuyán Basin}

The AFTB (Fig. 1c) developed in Miocene times (e.g., Ramos et al., 1996a; Giambiagi et al., 2003b) and preserves structures of previous extensional phases, superposed by tectonic inversion, the development of footwall shortcuts and both thick- and thin-skinned thrusting (e.g., Ramos 1988; Kozlowski et al., 1993; Cegarra and Ramos, 1996; Godoy, 1998; Pángaro et al., 1996; Ramos et al., 1996a; Álvarez et al., 1997; Álvarez and Ramos, 1999; Giambiagi et al., 2001, 2003a; Giambiagi and Ramos, 2002; Muñoz-Sáez et al., 2014). The Alto Tunuyán Basin began to develop on the eastern side of this fold-and-thrust belt. It contains a 1800 m thick sedimentary succession (Figs. 1 and 3) (e.g., Giambiagi, 1999, 2000; Giambiagi et al., 2003b). A similar syntectonic basin is the Cacheuta Foreland Basin (Fig. 1) (e.g., Giambiagi et al., 2003b; Buelow et al., 2014) located to the east of the Frontal Cordillera.

Giambiagi et al. (2003b) related different structures and deformation stages with sedimentary cycles and made a clast provenance study of the synorogenic Alto Tunuyán deposits, differentiating 3 units: the Tunuyán Conglomerate, the Palomares Formation and the Butaló Formation (Fig. 3). The paleogeographic and tectonic evolution model that they proposed shows a shift of the deformation front to the east, with several structural reactivations in the inner sector of the fold-and-thrust belt (see below).

\subsection{Tunuyán Conglomerate}

The first $200 \mathrm{~m}$ of the Tunuyán Conglomerate (Fig. 3) are composed mainly of volcanic materials, which come from the Cenozoic volcanic rocks of the Principal Cordillera on the Chilean side (Giambiagi, 1999). This part of the unit developed during the inversion of ancient normal faults in the basement (Giambiagi et al., 2003a). The next $1200 \mathrm{~m}$ of the Tunuyán Conglomerate contain clasts from the Lower Cretaceous limestone of the Mesozoic Mendoza Group and subsidiary Cenozoic volcanic rocks, and andesitic lavas and breccias intercalated in the succession (Fig. 3). The Tunuyán Conglomerate is related to a contractional event concentrated in the orogenic front of the AFTB with the development of in-sequence thrusts followed by out-of-sequence thrusts and fault reactivations (Giambiagi et al., 2003b).

\subsection{Palomares Formation}

This formation ( 200 m) (Fig. 3) is formed by an ignimbrite ( $84 \mathrm{~m}$ ) and sedimentary deposits ( $116 \mathrm{~m}$ ) composed of pinkish granitic, black shales and metamorphic clasts. These clasts have been interpreted as coming from the Proterozoic and late Paleozoic rocks of the Frontal Cordillera. The ignimbrite, named the 'Ignimbrita Arroyo Chileno' in this study, is composed of pyroclastic material that was previously described as a tuff (Ramos et al., 1996b) or sedimentary deposits (e.g., Giambiagi, 1999). It is slightly stratified and contains volcanic cinder, pumicitic clasts $(1-3 \mathrm{~cm})$, subrounded and subangular lithic clasts $(0.5-50 \mathrm{~cm})$, and pink granitic clasts in its basal part (Giambiagi, 1999). The evolutionary stage represented by the Palomares Formation was associated with a major uplift phase of the Frontal Cordillera and decreased activity of the AFTB (Giambiagi et al., 2003b).

\subsection{Butaló Formation}

This formation ( $240 \mathrm{~m}$ ) (Fig. 3) is a fine-grained and reddish sedimentary succession. Field descriptions by previous authors do not allow an accurate definition of its provenance. During its development, shortening was concentrated in the eastern Principal Cordillera with out-ofsequence thrusting in both the internal and external sectors of the AFTB. Activity in the AFTB came to an end with the uplift of the Frontal Cordillera (Giambiagi et al., 2003b). 

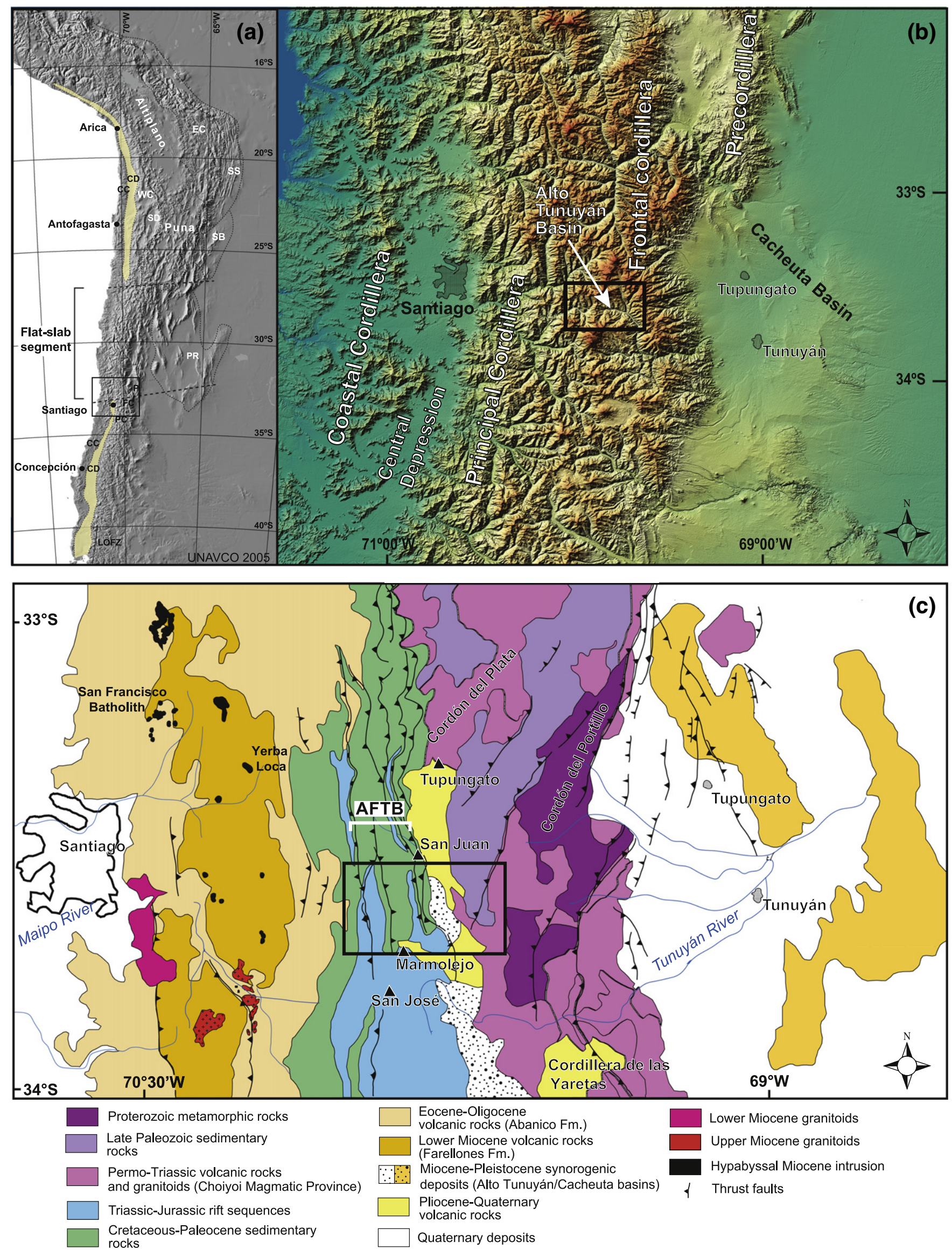

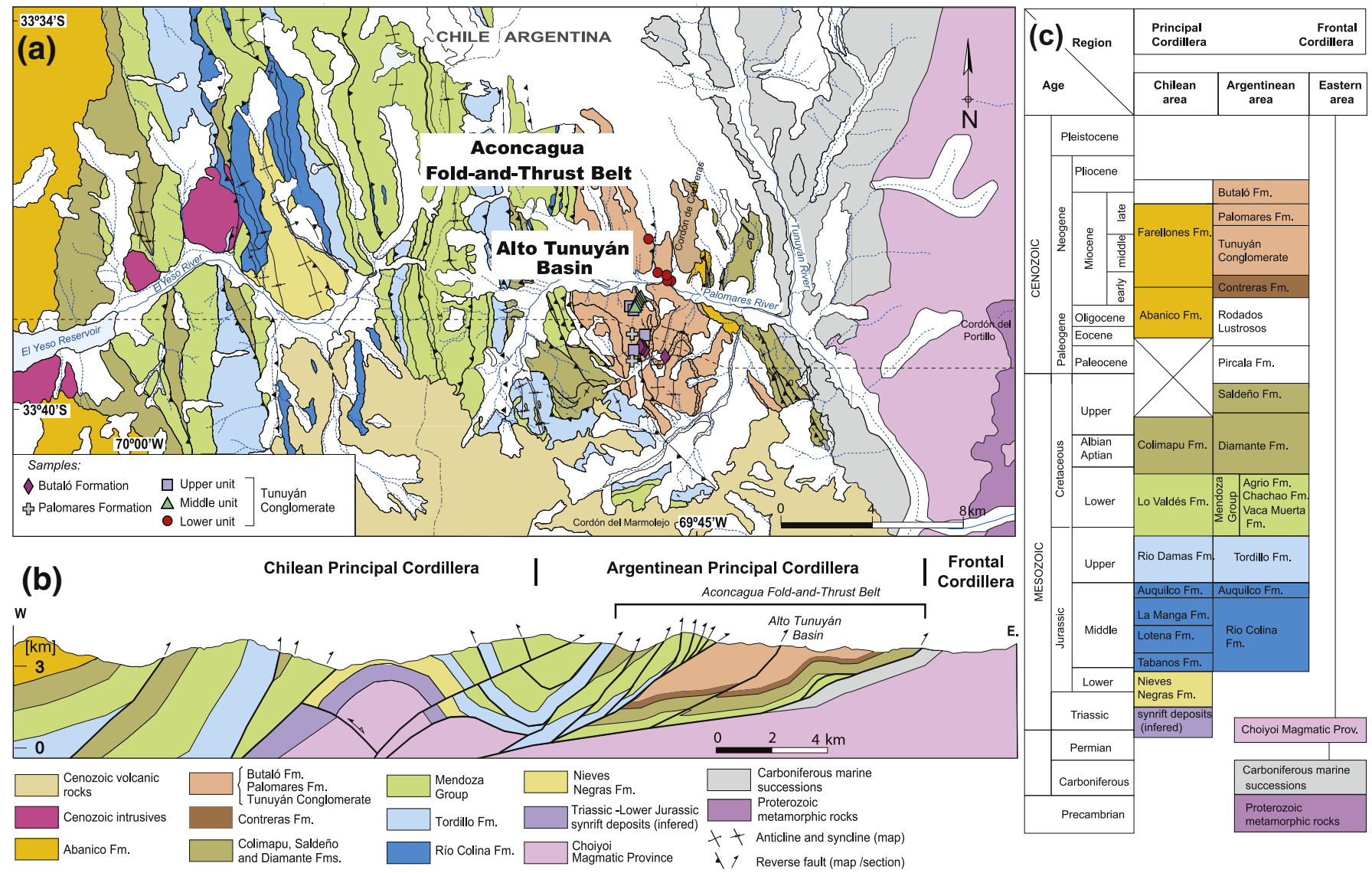

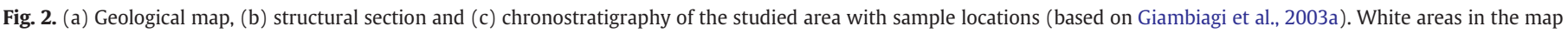
correspond to Quaternary units not shown in the cross-section.

\section{Potential source rocks of the Alto Tunuyán Basin}

Based on previous studies, the basement and potential source rocks of the Alto Tunuyán Basin are igneous and metamorphic rock units belonging to the Frontal Cordillera, and Mesozoic-Paleocene and Eocenemiddle Miocene volcanic and sedimentary rocks of the Principal Cordillera (Figs. 1c and 2) (e.g., González Díaz, 1958; Polanski, 1958; Caminos, 1979; Thiele, 1980; Charrier, 1981; Álvarez and Ramos, 1999; Álvarez et al., 2000). We present later the lithological characteristics and locations of the main geological units that bordered the Alto Tunuyán Basin, which are its the potential source rocks.

In the Frontal Cordillera, Cordón del Plata and Cordón del Portillo (Fig. 1c) the Guarguaráz Metamorphic Complex, composed of schists, gneisses and amphibolites of mainly late Mesoproterozoic age, crops out (e.g., González Díaz, 1958; Polanski, 1958; Ramos and Basei, 1997; Willner et al., 2008, 2011); this complex was affected by deformation and metamorphism between the middle Proterozoic and early Carboniferous (Pampean and Famatinian Orogenies) (see below) (e.g., Willner et al., 2008). The igneous rocks correspond to the late Permian-Triassic Choiyoi Group (e.g., Linares and González, 1990; Koukharsky, 1997; Kleiman and Japas, 2009; Martínez and Giambiagi, 2010) composed of basaltic, andesitic and rhyolitic lavas. The Permian Frontal Cordillera Composite Batholith is composed of granitic porphyries and plutons (Gregori and Benedini, 2013) and has been associated with the Choiyoi Group (e.g., Martínez and Giambiagi, 2010). For this reason, we consider those igneous units as representing the Choiyoi Magmatic Province.

The Mesozoic-Paleocene rocks in the Principal Cordillera correspond mainly to Jurassic successions composed of red and calcareous sandstones and limestones, black and calcareous shales and siltstones, limestones, and conglomerates, with basaltic-andesitic lavas, volcaniclastics, tuff and gypsum intercalations (Nieves Negras, Lotena, La Manga/Río Colina, Tordillo/Río Damas, Diamante/Colimapu, Saldeño, Pircala Formations and Mendoza Group [Vaca Muerta, Chachao and Agrio Formations/Lo Valdés Formation]) (e.g., Klohn, 1960; Thiele, 1980; Hallam et al., 1986; Legarreta and Gulisano, 1989; Godoy, 1993; Vergara and Nyström, 1996; Álvarez et al., 1997, 1999; Giambiagi, 1999, 2000; Tunik, 2003; Charrier et al., 2007).

The Eocene-middle Miocene rocks in the Chilean Principal Cordillera are represented by continental successions of lavas, tuffs, volcanic breccias and volcaniclastic sedimentary rocks of basaltic-andesitic affinity (Abanico Formation, ca. 37-23 Ma, and Farellones Formation, ca. 2317 Ma) (e.g., Klohn, 1960; Thiele, 1980; Charrier, 1981; Godoy et al., 1999; Charrier et al., 2002; Fuentes et al., 2002; Nyström et al., 2003; Fock et al., 2006; Muñoz-Sáez et al., 2014). Two pluton fringes intrude these units, one on the western side (ca. 20-18 Ma) and another on the eastern side of the Chilean Principal Cordillera (ca. 14-9 Ma), which correspond mainly to granodiorites, monzogranites and quartz

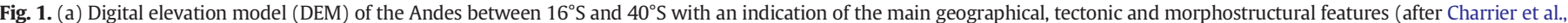

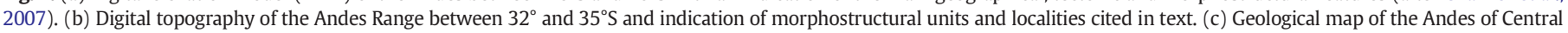

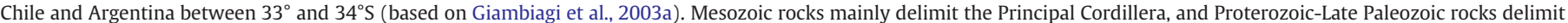

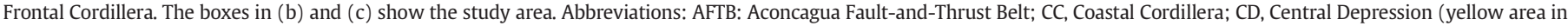

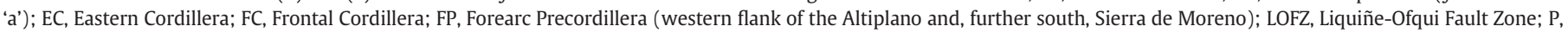
Precordillera in Argentina; PC, Principal Cordillera; PR, Pampean Ranges; SB, Santa Barbara System; SD, Salars Depression; SS, Subandean Sierras; WC, Western Cordillera. 


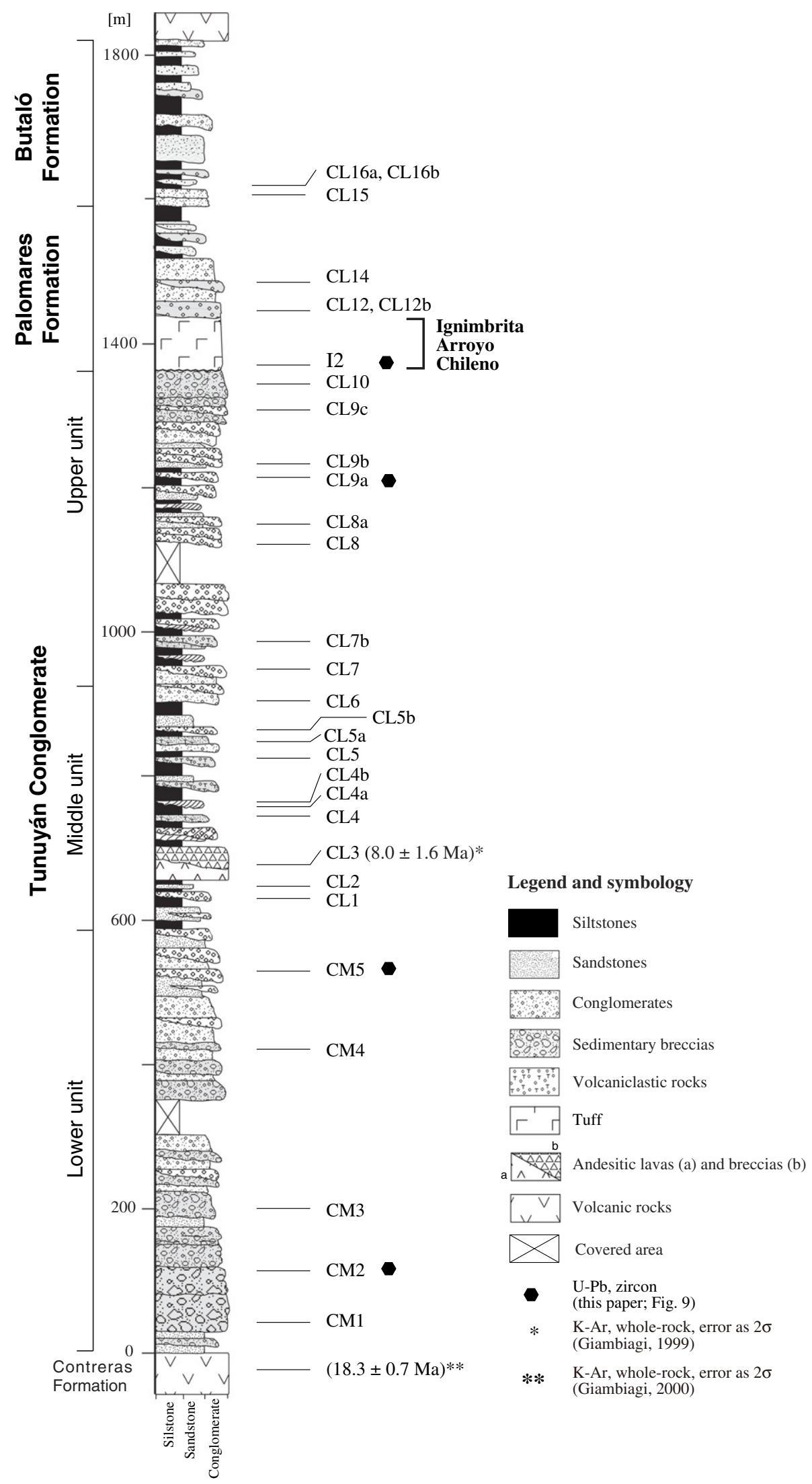

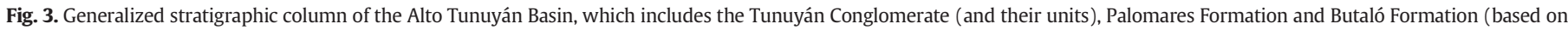

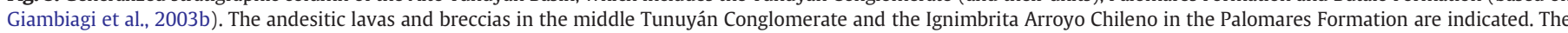
stratigraphic location of samples is also shown. 
monzonites with minor dioritic porphyries, dacites and andesites (e.g., Thiele 1980; Kurtz et al., 1997; Deckart et al., 2005, 2010). The Cenozoic rocks of the Argentinean Principal Cordillera are represented by the Contreras Formation (Polanski, 1964), which is composed of basaltic and andesitic lavas, breccias and tuffs (e.g., Polanski, 1964; Ramos et al., 1996b). It is located in a back-arc position with respect to the Chilean units at the base of the Alto Tunuyán Basin (Ramos et al., 2000). One age on its middle section (18.3 $\pm 0.7 \mathrm{Ma}$, K-Ar, whole-rock age; Giambiagi, 2000; Giambiagi et al., 2001; Giambiagi and Ramos, 2002) restricts the base of the Alto Tunuyán Basin to the early Miocene.

\section{Methodology}

Sampling in the Alto Tunuyán Basin was undertaken in the Palomares River area (Fig. 4a). Sandstone samples and the sandy matrix from conglomerates were collected for petrographic analysis $(n=25)$ and ${ }^{238} \mathrm{U} /{ }^{206} \mathrm{~Pb}$ LA-ICPMS dating of detrital zircons $(\mathrm{n}=4)$ (Table 1 and Figs. 3 and $4 a-f)$. We chose sandstone because this grain-size is a better global register of provenance in a region as several studies established (e.g., Morton and Hallsworth, 1999).
The samples were plotted according to their stratigraphic position in the succession (Tunuyán Conglomerate, Palomares Formation and Butaló Formation) as was defined by Giambiagi et al. (2003b). In addition, the Tunuyán Conglomerate was subdivided in the present study into three informal units (lower, middle and upper unit, Table 1 and Fig. 3) and we will reference them as the lower Tunuyán Conglomerate, the middle Tunuyán Conglomerate and the upper Tunuyán Conglomerate to facilitate the presentation of data.

\subsection{Petrographic analysis}

A modal analysis was carried out on the petrography of sandstone samples from the Tunuyán Conglomerate $(\mathrm{n}=22)$, the Palomares Formation $(\mathrm{n}=2)$, and the Butaló Formation $(\mathrm{n}=1)$ (Tables 1 and 2, Fig. 3 ). The sandstones were analysed using the Gazzi-Dickinson method (Table 2 and Figs. 5, 6 and 7), which is a point-counting technique used in geology to statistically measure the components of a sedimentary rock, chiefly sandstone (Dickinson, 1970; Ingersoll et al., 1984; Zuffa, 1985). In this study 400 or 500 points, according to the sample, were counted.
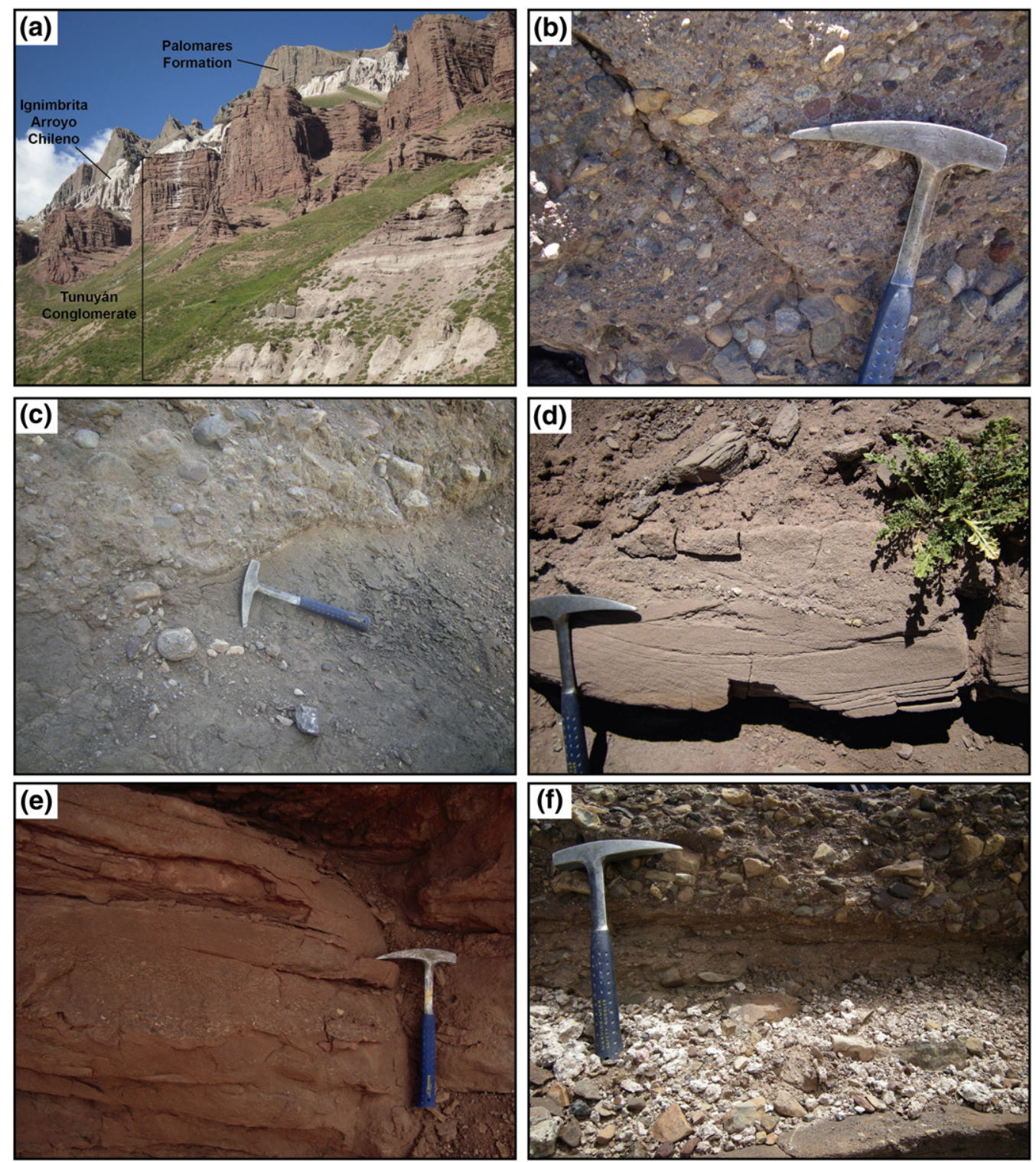

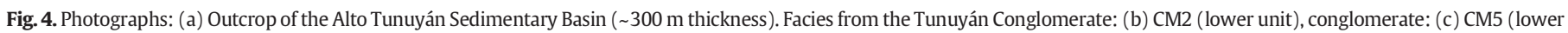
unit), sandstone: (d) CL7 (middle unit), sandstone (e) CL10 (upper unit), sandstones to siltstones: and facies from the Palomares Formation (f) CL12, conglomerate. 
Table 1

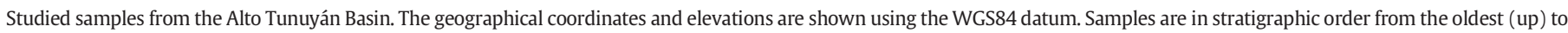
the youngest (down).

\begin{tabular}{|c|c|c|c|c|c|c|}
\hline Sample & Lithology & Latitude & Longitude & Elevation & Sandstone petrography & U-Pb/LA-ICPMS \\
\hline \multicolumn{7}{|c|}{$\begin{array}{l}\text { Tunuyán conglomerate } \\
\text { a) Lower unit }\end{array}$} \\
\hline CM1 & Sandstone matrix & $69^{\circ} 46^{\prime} 07^{\prime \prime}$ & $33^{\circ} 37^{\prime} 02^{\prime \prime}$ & 2997 & $\mathrm{X}$ & - \\
\hline CM2 & Sandstone matrix & $69^{\circ} 46^{\prime} 10^{\prime \prime}$ & $33^{\circ} 37^{\prime} 02^{\prime \prime}$ & 2989 & $\mathrm{X}$ & $\mathrm{X}$ \\
\hline CM3 & Sandstone matrix & $69^{\circ} 46^{\prime} 12^{\prime \prime}$ & $33^{\circ} 36^{\prime} 58^{\prime \prime}$ & 3011 & - & - \\
\hline CM4 & Sandstone matrix & $69^{\circ} 46^{\prime} 23^{\prime \prime}$ & $33^{\circ} 36^{\prime} 55^{\prime \prime}$ & 3016 & $\mathrm{X}$ & - \\
\hline CM5 & Sandstone & $69^{\circ} 46^{\prime} 32^{\prime \prime}$ & $33^{\circ} 27^{\prime} 21^{\prime \prime}$ & 3008 & $\mathrm{X}$ & $\mathrm{X}$ \\
\hline \multicolumn{7}{|c|}{ b) Middle unit } \\
\hline CL1 & Sandstone & $69^{\circ} 46^{\prime} 55^{\prime \prime}$ & $33^{\circ} 37^{\prime} 26^{\prime \prime}$ & 3028 & $\mathrm{X}$ & - \\
\hline CL2 & Sandstone & $69^{\circ} 46^{\prime} 56^{\prime \prime}$ & $33^{\circ} 37^{\prime} 27^{\prime \prime}$ & 3051 & $\mathrm{X}$ & - \\
\hline CL3 & Volcanic breccia & $69^{\circ} 46^{\prime} 56^{\prime \prime}$ & $33^{\circ} 37^{\prime} 27^{\prime \prime}$ & 3061 & - & - \\
\hline CL4 & Sandstone & $69^{\circ} 47^{\prime} 01^{\prime \prime}$ & $33^{\circ} 37^{\prime} 30^{\prime \prime}$ & 3115 & $\mathrm{X}$ & - \\
\hline CL4a & Sandstone & $69^{\circ} 47^{\prime} 01^{\prime \prime}$ & $33^{\circ} 37^{\prime} 30^{\prime \prime}$ & 3129 & $\mathrm{X}$ & - \\
\hline CL4b & Sandstone & $69^{\circ} 47^{\prime} 02^{\prime \prime}$ & $33^{\circ} 37^{\prime} 31^{\prime \prime}$ & 3135 & $\mathrm{X}$ & - \\
\hline $\mathrm{CL}^{\mathrm{a}}$ & Sandstone & $69^{\circ} 47^{\prime} 03^{\prime \prime}$ & $33^{\circ} 37^{\prime} 33^{\prime \prime}$ & 3158 & $\mathrm{X}$ & - \\
\hline CL5a & Sandstone & $69^{\circ} 47^{\prime} 03^{\prime \prime}$ & $33^{\circ} 37^{\prime} 35^{\prime \prime}$ & 3172 & $\mathrm{X}$ & - \\
\hline CL5b & Sandstone & $69^{\circ} 47^{\prime} 03^{\prime \prime}$ & $33^{\circ} 37^{\prime} 36^{\prime \prime}$ & 3185 & $\mathrm{X}$ & - \\
\hline CL6 & Sandstone & $69^{\circ} 47^{\prime} 05^{\prime \prime}$ & $33^{\circ} 37^{\prime} 39^{\prime \prime}$ & 3229 & - & - \\
\hline CL7 & Sandstone & $69^{\circ} 47^{\prime} 06^{\prime \prime}$ & $33^{\circ} 37^{\prime} 42^{\prime \prime}$ & 3258 & $\mathrm{X}$ & - \\
\hline $\mathrm{Cl} 7 \mathrm{~b}$ & Sandstone & $69^{\circ} 47^{\prime} 06^{\prime \prime}$ & $33^{\circ} 37^{\prime} 43^{\prime \prime}$ & 3284 & $\mathrm{X}$ & - \\
\hline \multicolumn{7}{|c|}{ c) Upper unit } \\
\hline CL8 & Sandstone & $69^{\circ} 47^{\prime} 09^{\prime \prime}$ & $33^{\circ} 37^{\prime} 45^{\prime \prime}$ & 3333 & $\mathrm{X}$ & - \\
\hline CL8a & Sandstone & $69^{\circ} 47^{\prime} 13^{\prime \prime}$ & $33^{\circ} 37^{\prime} 43^{\prime \prime}$ & 3301 & $\mathrm{X}$ & - \\
\hline CL9a & Sandstone & $69^{\circ} 47^{\prime} 18^{\prime \prime}$ & $33^{\circ} 37^{\prime} 42^{\prime \prime}$ & 3267 & $\mathrm{X}$ & $\mathrm{X}$ \\
\hline CL9b & Sandstone & $69^{\circ} 47^{\prime} 18^{\prime \prime}$ & $33^{\circ} 37^{\prime} 42^{\prime \prime}$ & 3268 & $\mathrm{X}$ & - \\
\hline $\mathrm{CL}^{\mathrm{a}} \mathrm{c}^{\mathrm{a}}$ & Sandstone & $69^{\circ} 47^{\prime} 09^{\prime \prime}$ & $33^{\circ} 38^{\prime} 49^{\prime \prime}$ & 3516 & $\mathrm{X}$ & - \\
\hline CL10 & Sandstone & $69^{\circ} 47^{\prime} 12^{\prime \prime}$ & $33^{\circ} 38^{\prime} 50^{\prime \prime}$ & 3645 & $\mathrm{X}$ & - \\
\hline \multicolumn{7}{|c|}{ Palomares Formation } \\
\hline I2 & Tuff & $69^{\circ} 47^{\prime} 21^{\prime \prime}$ & $33^{\circ} 38^{\prime} 24^{\prime \prime}$ & 3654 & - & $\mathrm{X}$ \\
\hline CL12 & Sandstone matrix & $69^{\circ} 47^{\prime} 11^{\prime \prime}$ & $33^{\circ} 39^{\prime} 07^{\prime \prime}$ & 3698 & $\mathrm{X}$ & $\mathrm{X}$ \\
\hline CL12b & Sandstone matrix & $69^{\circ} 47^{\prime} 11^{\prime \prime}$ & $33^{\circ} 39^{\prime} 07^{\prime \prime}$ & 3698 & $\mathrm{X}$ & - \\
\hline CL14 & Sandstone matrix & $69^{\circ} 47^{\prime} 13^{\prime \prime}$ & $33^{\circ} 38^{\prime} 35^{\prime \prime}$ & 3507 & - & - \\
\hline \multicolumn{7}{|c|}{ Butaló Formation } \\
\hline CL15 & Sandstone & $69^{\circ} 46^{\prime} 49^{\prime \prime}$ & $33^{\circ} 39^{\prime} 00^{\prime \prime}$ & 3501 & - & - \\
\hline CL16a & Shale & $69^{\circ} 46^{\prime} 54^{\prime \prime}$ & $33^{\circ} 38^{\prime} 58^{\prime \prime}$ & 3572 & $\mathrm{X}$ & - \\
\hline CL16b & Sandstone & $69^{\circ} 46^{\prime} 54^{\prime \prime}$ & $33^{\circ} 38^{\prime} 58^{\prime \prime}$ & 3572 & - & - \\
\hline
\end{tabular}

a CL5 and CL9c samples have duplicates for the petrological analysis (CL5(1), CL5(2), CL9c1, CL9c2).

The major detrital framework components were normalized to $100 \%$ (Table 2), using the classification outlined in Folk et al. (1970) (Fig. 7a). Quartz, feldspar and lithic fragments (QFL) diagrams were plotted as in Dickinson et al. (1983) (Fig. 7b). Quartz grains identified in volcanic rock fragments were counted separately, but as they were $<2 \%$ of the total amount of monocrystalline quartz, they were included into the monocrystalline undulose type in order to simplify the chart. The polycrystalline quartz (Qpq) was further divided into three groups (according to Basu, 1985): Polycrystalline quartz with 2-3 subgrains, polycrystalline with 4 subgrains and polycrystalline with $>4$ subgrains. The feldspar was subdivided into alkali feldspars (orthoclase and microcline) and plagioclase, with the latter being the most common type. In the original count, altered feldspar and feldspar identified in rock fragments were counted separately as suggested by Dickinson (1970), Ingersoll et al. (1984) and Zuffa (1985), but when they represent $<10 \%$ of the counted categories, they were included in the feldspars and plagioclase single crystal categories.

\section{2. ${ }^{238} \mathrm{U}^{206} \mathrm{~Pb}$ LA-ICPMS analysis}

Four zircon samples were prepared for U-Pb geochronology: CM2 and CM5 from the lower Tunuyán Conglomerate, CL9a from the top of the upper Tunuyán Conglomerate, and I2 from the Ignimbrita Arroyo Chileno (Table 1 and Fig. 3). Detrital zircons were separated using standard preparation methods at the Departamento de Geología, Universidad de Chile, using the Gemini table, Frantz magnetic separator and heavy liquid procedures. Final grain selection was undertaken by hand-picking, using a binocular microscope.
One zircon mineral sample ( $\mathrm{CM} 2)$ was then sent for analysis to the Laboratorio de Estudios Isotópicos (LEI), Geoscience Center, Universidad Nacional Autónoma de México (UNAM), Mexico. The analytical work was undertaken by using a Resonetics Resolution M50 193 nm laser Excimer connected to a Thermo Xii Series Quadrupole Mass Spectrometer (LA-ICPMS) following analytical procedures and technical details given in Solari et al. (2010). The laser diameter employed for ablations was $34 \mu \mathrm{m}$. Detrital zircon ${ }^{238} \mathrm{U} /{ }^{206} \mathrm{~Pb}$ ages were calculated on 98 individual ablation spots using Isoplot v. 3.70 (Ludwig, 2008). The error in ${ }^{238} \mathrm{U} /{ }^{206} \mathrm{~Pb}$ ages generally is $<1.5 \%(1 \sigma)$. Reference material (e.g., Plesovice, 337 Ma; Sláma et al., 2008) indicates accuracy on isotopic ratios that ranged from about 2 to $6 \%$ depending on the homogeneity of the employed reference material.

The other three samples (CM5, CL9a, I2) were sent to the Washington State University, United States. Analyses were obtained through the LA-ICPMS ThermoFinnigan Element 2 coupled to a New Wave Nd YAGUV $213 \mathrm{~nm}$ laser. Details for procedures and operating parameters are given in Chang et al. (2006). The laser spot size was $30 \mu \mathrm{m}$. Used zircon standards were Peixe of $564 \mathrm{Ma}$ (Dickinson and Gehrels, 2003) and FC-1 of $1099 \mathrm{Ma}$ (Paces and Miller, 1993). About 100 ablations on each sample were obtained and treated to calculate ${ }^{238} \mathrm{U} /{ }^{206} \mathrm{~Pb}$ ages through Isoplot v. 3.0 (Ludwig, 2003).

In all cases, the best age recommended by the corresponding laboratory was adopted. For the single sample analysed at LEI (UNAM), ${ }^{206} \mathrm{~Pb} /{ }^{238} \mathrm{U}$ ages were considered if they were younger than $1150 \mathrm{Ma}$, above this age, ${ }^{207} \mathrm{~Pb} /{ }^{206} \mathrm{~Pb}$ ages were preferred. Regarding $\mathrm{U}-\mathrm{Pb}$ ages supplied by the Washington State University, ${ }^{206} \mathrm{~Pb} /{ }^{238} \mathrm{U}$ ages were considered if ages were younger than $1000 \mathrm{Ma}$; in case of older ages the ${ }^{207} \mathrm{~Pb} /{ }^{206} \mathrm{~Pb}$ ages were favoured. 
Table 2

Percentage of minerals and lithics in sandstones of the Alto Tunuyán Basin.

\begin{tabular}{|c|c|c|c|c|c|c|c|c|c|c|c|c|c|c|c|c|c|c|c|c|c|c|c|c|c|c|c|}
\hline & & & \multicolumn{22}{|c|}{ Tunuyán Conglomerate } & \multirow{2}{*}{\multicolumn{2}{|c|}{$\begin{array}{l}\text { Palomares } \\
\text { Fm. }\end{array}$}} & \multirow{3}{*}{$\begin{array}{l}\text { Butaló } \\
\text { Fm. } \\
\text { CL16b }\end{array}$} \\
\hline & & & \multicolumn{4}{|c|}{ Lower unit } & \multicolumn{11}{|c|}{ Middle unit } & \multicolumn{7}{|c|}{ Upper unit } & & & \\
\hline & & & CM1 & CM2 & CM4 & CM5 & CL1 & CL2 & CL4 & CL4a & CL4b & $\begin{array}{l}\text { CL5 } \\
(1) \\
\end{array}$ & $\begin{array}{l}\text { CL5 } \\
(2) \\
\end{array}$ & CL5a & CL5b & CL7 & CL7b & CL8 & CL8a & CL9a & CL 9b & CL9c1 & CL9c2 & CL10 & CL12 & CL12b & \\
\hline \multirow[t]{5}{*}{ Quartz } & Mono-crystalline & Ondulose & 0.00 & 3.50 & 0.50 & 0.25 & 7.75 & 1.00 & 1.00 & 0.75 & 0.50 & 4.25 & 0.75 & 0.75 & 0.00 & 2.25 & 1.25 & 0.25 & 0.00 & 2.25 & 4.00 & 6.75 & 1.25 & 0.25 & 2.75 & 0.75 & 1.25 \\
\hline & & Non-ondulose & 18.75 & 6.00 & 7.25 & 14.75 & 7.25 & 26.25 & 14.50 & 15.00 & 9.75 & 7.75 & 10.75 & 12.00 & 13.50 & 19.25 & 17.75 & 24.50 & 35.00 & 28.75 & 9.25 & 5.75 & 9.25 & 27.50 & 21.25 & 23.81 & 25.75 \\
\hline & Poly-crystalline & 3 grains & 0.75 & 0.75 & 0.00 & 0.25 & 1.50 & 0.75 & 0.00 & 0.75 & 0.00 & 0.00 & 0.25 & 0.50 & 0.00 & 0.00 & 0.00 & 0.00 & 0.50 & 0.50 & 1.00 & 1.00 & 0.25 & 0.25 & 0.00 & 0.00 & 0.00 \\
\hline & & 4 grains & 0.00 & 0.00 & 0.00 & 0.00 & 0.00 & 0.00 & 0.25 & 0.00 & 0.00 & 0.00 & 0.00 & 0.00 & 0.00 & 0.00 & 0.00 & 0.00 & 0.00 & 0.25 & 0.25 & 0.00 & 0.00 & 0.00 & 0.00 & 0.00 & 0.50 \\
\hline & & $\begin{array}{l}\text { More than } 5 \\
\text { grains }\end{array}$ & 0.25 & 0.00 & 0.00 & 0.00 & 0.00 & 1.25 & 0.75 & 0.50 & 0.50 & 0.25 & 0.50 & 0.00 & 1.00 & 0.75 & 0.00 & 0.75 & 0.50 & 1.00 & 2.00 & 0.50 & 0.50 & 0.50 & 0.00 & 0.25 & 0.25 \\
\hline \multirow[t]{3}{*}{ Feldspar } & & Plagioclase & 9.50 & 11.00 & 26.75 & 25.00 & 9.75 & 8.00 & 26.25 & 38.00 & 27.75 & 21.50 & 27.25 & 34.50 & 25.50 & 20.25 & 23.00 & 23.00 & 13.50 & 11.50 & 12.00 & 14.50 & 19.50 & 13.00 & 19.25 & 11.03 & 18.00 \\
\hline & & Microcline & 0.00 & 0.25 & 0.00 & 0.00 & 0.00 & 0.00 & 0.00 & 0.00 & 0.00 & 0.50 & 0.00 & 0.00 & 0.00 & 0.00 & 0.00 & 0.00 & 0.00 & 0.00 & 0.00 & 0.75 & 0.00 & 0.00 & 0.00 & 0.00 & 0.00 \\
\hline & & Orthoclase & 3.25 & 2.75 & 1.00 & 1.75 & 4.50 & 4.75 & 2.50 & 1.75 & 5.00 & 7.75 & 3.25 & 2.00 & 2.00 & 5.00 & 1.00 & 2.75 & 6.75 & 6.25 & 11.00 & 6.50 & 6.75 & 6.75 & 4.25 & 8.52 & 6.25 \\
\hline \multirow[t]{9}{*}{$\begin{array}{l}\text { Rock } \\
\text { fragments }\end{array}$} & $\begin{array}{l}\text { Volcanic rock } \\
\text { fragments }\end{array}$ & $\begin{array}{l}\text { With seriate } \\
\text { textures }\end{array}$ & 10.00 & 19.00 & 2.00 & 3.00 & 13.75 & 2.00 & 6.00 & 5.75 & 0.75 & 1.00 & 2.75 & 2.00 & 3.00 & 1.50 & 5.00 & 1.50 & 7.25 & 7.75 & 3.00 & 1.00 & 1.00 & 5.25 & 1.50 & 2.51 & 0.25 \\
\hline & & $\begin{array}{l}\text { With granular } \\
\text { textures }\end{array}$ & 7.50 & 1.25 & 3.75 & 0.75 & 0.00 & 9.00 & 8.50 & 1.50 & 3.25 & 5.00 & 3.25 & 3.00 & 3.75 & 7.75 & 6.00 & 4.25 & 3.75 & 5.25 & 6.00 & 2.25 & 0.25 & 4.25 & 6.00 & 10.78 & 8.00 \\
\hline & & $\begin{array}{l}\text { With microlithic } \\
\text { textures }\end{array}$ & 21.25 & 18.50 & 20.25 & 13.75 & 11.50 & 6.50 & 11.75 & 11.00 & 14.75 & 10.75 & 14.50 & 24.00 & 27.00 & 13.25 & 22.00 & 18.25 & 6.75 & 3.00 & 6.00 & 12.50 & 17.25 & 6.75 & 5.75 & 12.78 & 8.50 \\
\hline & & $\begin{array}{l}\text { With lathwork } \\
\text { textures }\end{array}$ & 3.50 & 1.50 & 1.75 & 0.50 & 0.25 & 1.00 & 0.50 & 0.00 & 2.75 & 1.75 & 4.00 & 0.25 & 0.75 & 1.00 & 0.50 & 0.75 & 0.00 & 0.25 & 0.00 & 0.75 & 2.75 & 0.25 & 2.25 & 0.25 & 3.00 \\
\hline & & $\begin{array}{l}\text { With vitric } \\
\text { textures }\end{array}$ & 3.25 & 5.25 & 1.25 & 1.25 & 1.25 & 1.50 & 0.75 & 1.25 & 1.25 & 2.75 & 0.50 & 0.50 & 1.00 & 0.75 & 3.25 & 1.00 & 0.00 & 0.50 & 0.50 & 8.00 & 1.00 & 1.00 & 3.75 & 2.01 & 0.00 \\
\hline & Methamorphic & & 0.00 & 0.00 & 0.00 & 0.00 & 0.75 & 1.25 & 0.50 & 0.00 & 0.00 & 0.00 & 0.00 & 0.25 & 0.25 & 0.50 & 0.00 & 0.00 & 0.50 & 0.25 & 0.25 & 0.50 & 0.25 & 1.25 & 1.25 & 0.50 & 0.75 \\
\hline & Sedimentary & & 7.25 & 3.25 & 1.75 & 1.00 & 10.00 & 8.50 & 3.25 & 2.50 & 8.50 & 4.00 & 0.25 & 1.00 & 0.50 & 4.50 & 0.00 & 3.25 & 2.25 & 6.50 & 5.00 & 3.25 & 0.25 & 10.00 & 4.75 & 0.00 & 3.25 \\
\hline & Pseudomatrix & & 0.00 & 4.50 & 0.00 & 25.75 & 0.00 & 2.00 & 2.25 & 0.00 & 1.00 & 4.25 & 5.50 & 0.25 & 0.75 & 0.00 & 3.00 & 6.75 & 0.00 & 0.00 & 3.50 & 3.50 & 15.25 & 1.50 & 1.00 & 8.27 & 2.00 \\
\hline & Altered lithics & & 0.00 & 2.50 & 3.50 & 2.75 & 3.50 & 2.00 & 1.25 & 3.25 & 0.75 & 3.75 & 2.25 & 2.50 & 3.00 & 1.75 & 1.75 & 0.75 & 1.25 & 4.50 & 3.75 & 1.50 & 1.75 & 2.00 & 2.25 & 2.26 & 3.00 \\
\hline \multirow{3}{*}{$\begin{array}{l}\text { Accessory } \\
\text { minerals }\end{array}$} & Heavy minerals & & 1.50 & 0.75 & 2.75 & 3.25 & 2.50 & 1.75 & 2.75 & 2.50 & 4.50 & 3.25 & 4.00 & 2.75 & 2.50 & 4.00 & 1.25 & 3.00 & 3.50 & 5.25 & 0.50 & 2.50 & 4.50 & 3.00 & 6.00 & 2.01 & 2.25 \\
\hline & Other minerals & & 0.00 & 4.00 & 4.25 & 2.25 & 0.25 & 0.50 & 2.25 & 0.25 & 1.00 & 0.00 & 0.00 & 1.75 & 1.00 & 0.00 & 7.75 & 2.75 & 0.00 & 1.00 & 1.25 & 5.50 & 4.50 & 0.75 & 0.50 & 0.25 & 0.25 \\
\hline & Mica & & 0.00 & 0.00 & 0.00 & 0.00 & 0.50 & 0.00 & 0.25 & 0.75 & 0.00 & 0.25 & 0.00 & 0.75 & 0.25 & 0.75 & 3.75 & 1.75 & 0.25 & 0.75 & 0.00 & 0.25 & 0.75 & 0.00 & 1.00 & 0.00 & 0.00 \\
\hline \multirow[t]{3}{*}{ Cements } & Iron oxides & & 0.00 & 0.00 & 0.00 & 0.00 & 0.50 & 0.00 & 0.00 & 0.00 & 0.00 & 0.50 & 0.00 & 0.00 & 0.00 & 0.00 & 0.00 & 0.00 & 4.00 & 0.00 & 3.75 & 0.00 & 0.00 & 0.00 & 3.25 & 0.00 & 0.00 \\
\hline & Calcareous & & 11.50 & 12.50 & 21.50 & 1.25 & 23.75 & 21.75 & 13.00 & 14.25 & 15.75 & 13.00 & 10.75 & 9.75 & 12.00 & 16.00 & 0.75 & 3.50 & 13.75 & 14.50 & 18.00 & 18.75 & 11.25 & 9.25 & 13.25 & 9.02 & 14.00 \\
\hline & Argillaceous & & 0.00 & 0.00 & 0.00 & 0.00 & 0.00 & 0.00 & 1.50 & 0.00 & 2.00 & 4.50 & 7.75 & 1.00 & 2.25 & 0.00 & 1.50 & 0.75 & 0.50 & 0.00 & 6.00 & 2.50 & 0.75 & 5.00 & 0.00 & 0.00 & 0.00 \\
\hline \multicolumn{3}{|l|}{ Porosity } & 1.75 & 2.75 & 1.75 & 2.50 & 0.75 & 0.25 & 0.25 & 0.25 & 0.25 & 3.25 & 1.75 & 0.50 & 0.00 & 0.75 & 0.50 & 0.50 & 0.00 & 0.00 & 3.00 & 1.50 & 1.00 & 1.50 & 0.00 & 5.01 & 2.75 \\
\hline \multicolumn{3}{|c|}{ Total } & 100 & 100 & 100 & 100 & 100 & 100 & 100 & 100 & 100 & 100 & 100 & 100 & 100 & 100 & 100 & 10 & 100 & 100 & 100 & 100 & 100 & 100 & 100 & 100 & 100 \\
\hline \multirow{2}{*}{\multicolumn{3}{|c|}{$\begin{array}{l}\mathrm{P} / \mathrm{Ft} \\
\mathrm{Qt}=\text { total quartz }\end{array}$}} & 0.75 & 0.79 & 0.96 & 0.93 & 0.68 & 0.63 & 0.91 & 0.96 & 0.85 & 0.72 & 0.89 & 0.95 & 0.93 & 0.80 & 0.96 & 0.89 & 0.67 & 0.65 & 0.52 & 0.67 & 0.74 & 0.66 & 0.82 & 0.56 & 0.74 \\
\hline & & & 19.75 & 10.25 & 7.75 & 15.25 & 16.50 & 29.25 & 16.50 & 17.00 & 10.75 & 12.25 & 12.25 & 13.25 & 14.50 & 22.25 & 19.00 & 25.50 & 36.00 & 32.75 & 16.50 & 14.00 & 11.25 & 28.50 & 24.00 & 24.81 & 27.75 \\
\hline \multirow{2}{*}{\multicolumn{3}{|c|}{$\mathrm{F}=$ total feldspar }} & 12.75 & 14.00 & 27.75 & 26.75 & 14.25 & 12.75 & 28.75 & 39.75 & 32.75 & 29.75 & 30.50 & 36.50 & 27.50 & 25.25 & 24.00 & 25.75 & 20.25 & 17.75 & 23.00 & 21.75 & 26.25 & 19.75 & 23.50 & 19.55 & 24.25 \\
\hline \multicolumn{2}{|c|}{$\mathrm{L}=$ total lithics } & & 52.75 & 55.75 & 34.25 & 48.75 & 41.00 & 33.75 & 34.75 & 25.25 & 33.00 & 33.25 & 33.00 & 33.75 & 40.00 & 31.00 & 41.50 & 36.50 & 21.75 & 28.00 & 28.00 & 33.25 & 39.75 & 32.25 & 28.50 & 39.35 & 28.75 \\
\hline \multicolumn{3}{|c|}{ Total quartz $1=$ undulose and non-undulose } & 18.75 & 9.50 & 7.75 & 15.00 & 15.00 & 27.25 & 15.50 & 15.75 & 10.25 & 12.00 & 11.50 & 12.75 & 13.50 & 21.50 & 19.00 & 24.75 & 35.00 & 31.00 & 13.25 & 12.50 & 10.50 & 27.75 & 24.00 & 24.56 & 27.00 \\
\hline Total quartz 2 & $=$ polycrystalline & & 1.00 & 0.75 & 0.00 & 0.25 & 1.50 & 2.00 & 1.00 & 1.25 & 0.50 & 0.25 & 0.75 & 0.50 & 1.00 & 0.75 & 0.00 & 0.75 & 1.00 & 1.75 & 3.25 & 1.50 & 0.75 & 0.75 & 0.00 & 0.25 & 0.75 \\
\hline$\%$ Acidic volca & ic fragments ${ }^{\mathrm{a}}$ & & 17.50 & 20.25 & 5.75 & 3.75 & 13.75 & 11.00 & 14.50 & 7.25 & 4.00 & 6.00 & 6.00 & 5.00 & 6.75 & 9.25 & 11.00 & 5.75 & 11.00 & 13.00 & 9.00 & 3.25 & 1.25 & 9.50 & 7.50 & 13.28 & 8.25 \\
\hline$\%$ Basic volcar & $\mathrm{c}$ fragments $\mathrm{s}^{\mathrm{b}}$ & & 24.75 & 20.00 & 22.00 & 14.25 & 11.75 & 7.50 & 12.25 & 11.00 & 17.50 & 12.50 & 18.50 & 24.25 & 27.75 & 14.25 & 22.50 & 19.00 & 6.75 & 3.25 & 6.00 & 13.25 & 20.00 & 7.00 & 8.00 & 13.03 & 11.50 \\
\hline
\end{tabular}

a \%Acidic $=$ volcanic rocks with seriate and granular textures.

b $\%$ Basic = volcanic rocks with microlithic and lathwork textures. 

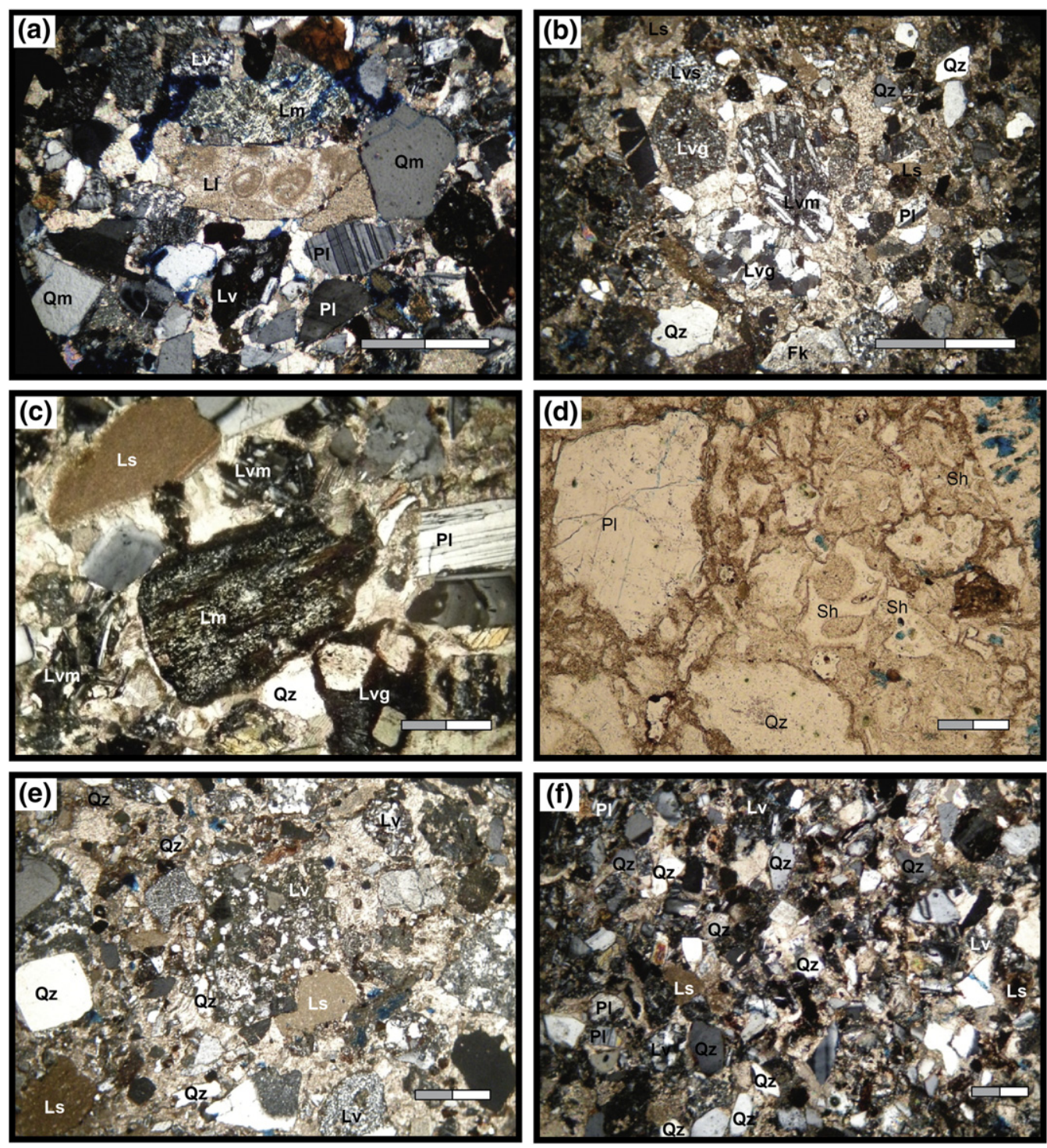

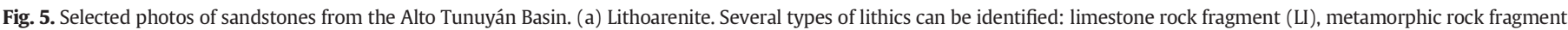

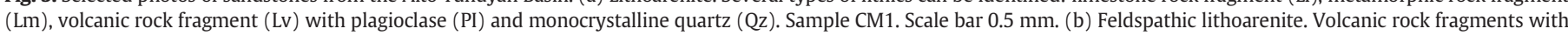

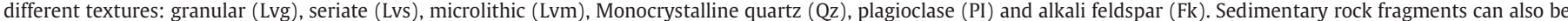

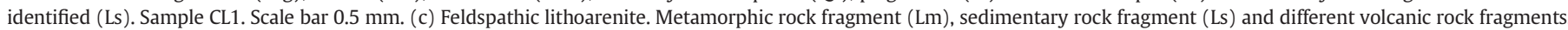

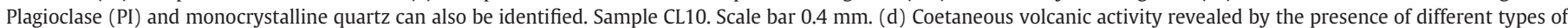

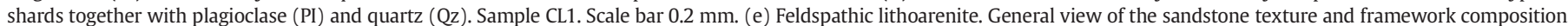

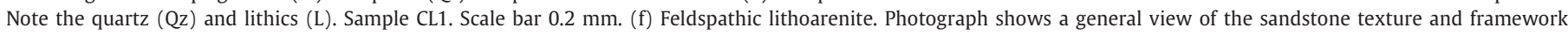
composition. Notice the increase in the amount of quartz $(\mathrm{Qz})$ in this sample compared to CL1 in 'e'. Sample CL16. Scale bar $0.2 \mathrm{~mm}$.

\section{Petrography: Character of the sources}

In this section, the detrital components of the studied succession, their distribution within the stratigraphic column and the kind of rocks that supplied detritus to the basin are described and established. The main components of the sandstones are quartz, feldspars and lithic fragments (Table 2). We identified five different classes of quartz, three categories of feldspar, nine different types of lithic fragments, three different types of cement, as well as heavy minerals, micas and other minor mineral grains (Table 2 and Fig. 5).

The percentage of total quartz observed in the studied section was variable (7.75-36\%, Table 2 and Fig. 6a) with a general increase in the quartz proportion from the base of the succession to the top (Fig. 6a). Monocrystalline and polycrystalline quartz were identified. Monocrystalline quartz occurred in two variants: non-undulose (flash) and undulose (Basu, 1985; Tortosa et al., 1991). The non-undulose quartz is the most important in the succession. The Butalo Formation presents a high concentration of total quartz (27.75\%) (Table 2), still, it should be noted that this unit is only represented by one fine-grained sample.

The amount of total feldspar was quite variable (12.75-39.75\%, Table 2 and Fig. 6b). Three trends could be observed. In the lower and middle Tunuyán Conglomerate, the amount increases from base to top, and then, after reaching a maximum of $39.75 \%$ in the middle unit, it constantly decreases up to the upper unit and the trend continues to increase in the Butaló Formation (Table 2 and Fig. 6b). Nonetheless, the P/Ft ratio ( $\mathrm{P}$ : plagioclase, Ft: total feldspar) presented a high variation from 0.52 to 0.96 (Fig. 6g). Dickinson (1970) proposed that material derived from volcanic terrains should have a P/Ft ratio from 0.75 to 1.00 , which indicates that most of the deposits of the Alto Tunuyán Basin have a significant volcanic source, being more significant in the lower and middle Tunuyán Conglomerate (Fig. $6 \mathrm{~g}$ ). K-feldspar is quite variable in the lower and middle Tunuyán Conglomerate, but almost constant in the upper unit (Fig. 6h and Table 2). Plagioclase is well related to the basic volcanic lithics identified in the middle and upper Tunuyán 


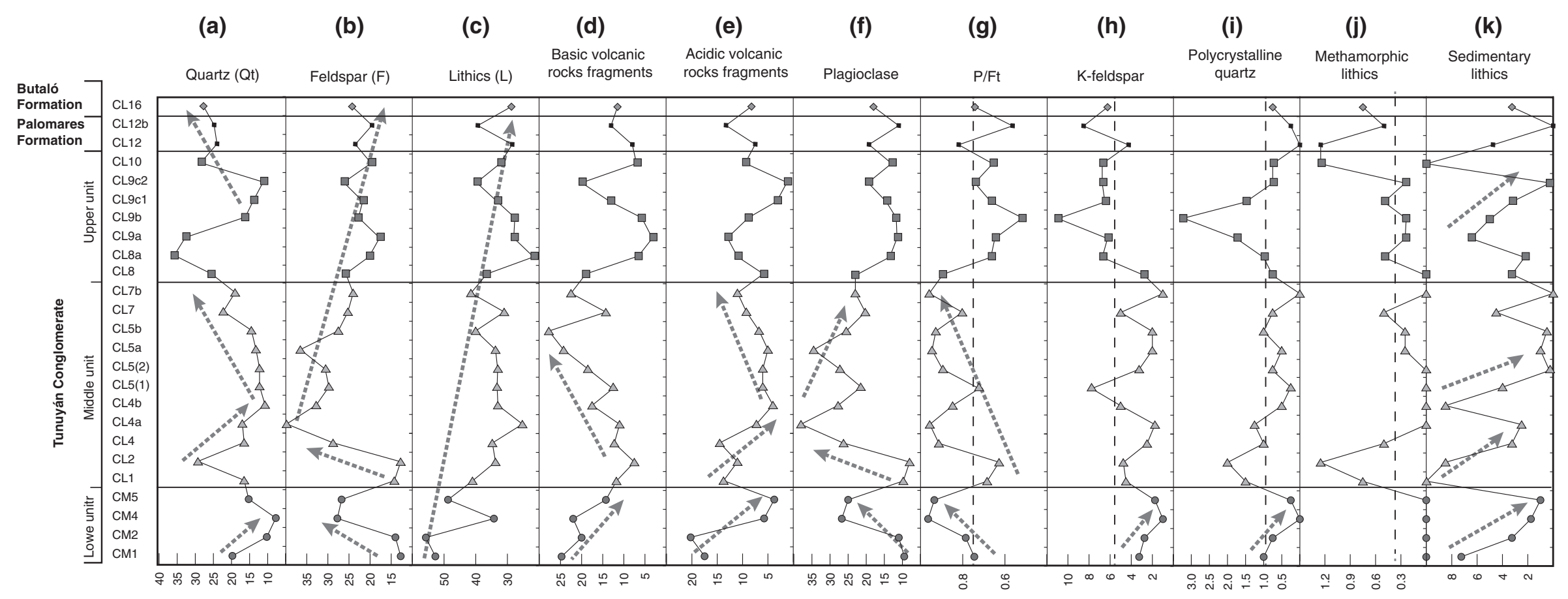

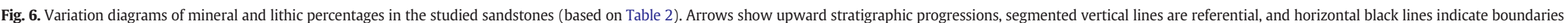
between units. 


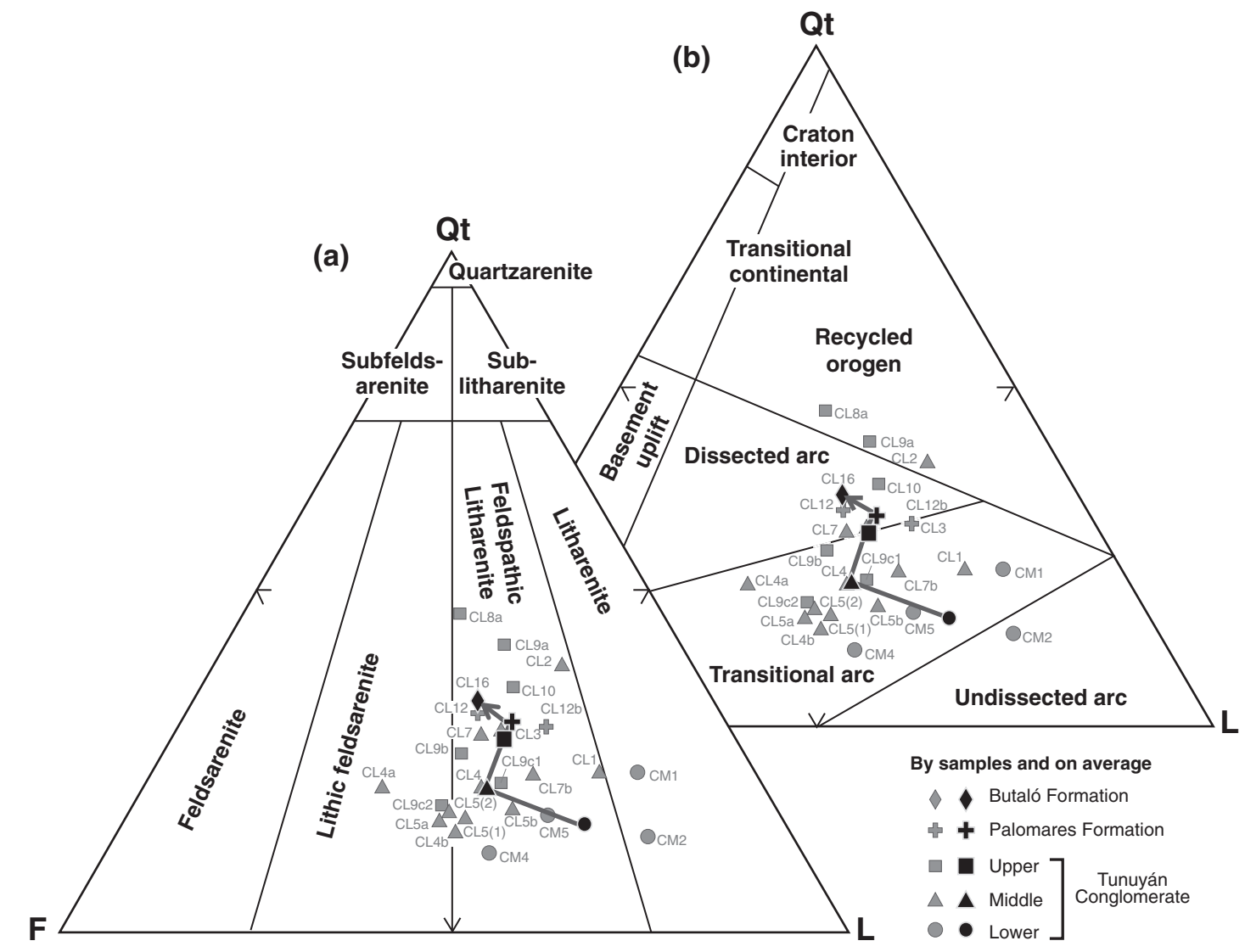

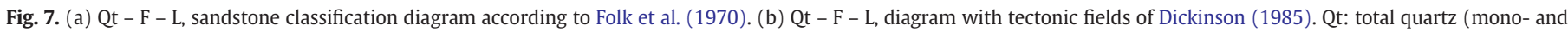

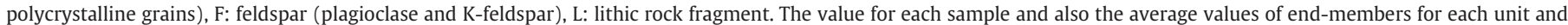
subunit are plotted.

Conglomerate, especially from sample CL4b (correlation coefficient, $\mathrm{r}=$ +0.8 ) (Fig. 6d, f and Table 2).

Rock fragments are the most common detrital constituents of the samples (21.75-55.75\%, Table 2 and Fig. 6c). Volcanic, sedimentary and metamorphic lithics were identified, the volcanic fragments being most abundant (Table 2 and Fig. 6c). Also, pseudomatrix and some altered lithics were distinguished. All the samples have both basic and acidic volcanic fragments in variable quantities (Table 2 and Fig. 6d, e), the basic types with microlitic texture being most abundant ( 3$27 \%$ ). The lower and middle units of the Tunuyán Conglomerate have the highest concentration of basic volcanic fragments ( $16-20 \%$, on average) (Table 2 and Fig. 6d). In general, all the samples show scarce and variable amounts $(\leq 10 \%)$ of sedimentary rock fragments (sandstones, siltstones, shales and limestones); these variations correlate slightly with variations in the polycrystalline quartz and metamorphic lithic content (Fig. 6i-k). The metamorphic lithics are very scarce $(\leq 1.25 \%$, Fig. 6j) between the middle Tunuyán Conglomerate and the Butaló Formation, being absent from the lower Tunuyán Conglomerate.

Furthermore, correlations between the abundance of certain materials were identified following the stratigraphy (Fig. 6): a) The K-feldspar and polycrystalline quartz present a similar variation pattern $(\mathrm{r}=+0.5)$, characterizing most probably the same source rocks. Besides, they show a negative correlation with plagioclase $(r=-0.8 \mathrm{~K}-$ Fd vs. Plag and $r=-0.4$ PQz vs. Plag) in the lower unit and at the base of the middle Tunuyán Conglomerate, indicating different sources during these periods. b) The plagioclase has a similar pattern compared with the basic volcanic fragments in the upper Tunuyán Conglomerate $(\mathrm{r}=+0.9)$, implying that the plagioclase is contained in the basic volcanic source for this period. c) There is a well-defined inverse correlation between the plagioclase and acidic volcanic fragments (except
CL4) $(r=-0.6)$, which implies that they register different kinds of source rocks, possibly one acidic and another basic.

Finally, samples are mainly classified as feldspathic litharenites (Fig. 7a). Nevertheless, if the average values per unit and subunit are considered, the succession shows a general trend from litharenites towards feldspathic litharenites related to the general upward increase in quartz and decrease in volcanic fragments (Figs. 6a and 7a). This trend indicates that source rocks progressed from a transitional arc to a dissected arc (Fig. 7b).

\section{Detrital zircon geochronology}

Detrital zircons are generally transparent and colourless. Only one sample (CL9a) shows pinkish to light brown colours. Two populations of zircons were identified: one group characterized by an euhedral (to subhedral in sample CL9a) and prismatic habit with oscillatory growth zoning (Fig. 8); the other group is characterized by a subspherical, subrounded to rounded habit, without any internal structures observed in CL images (Fig. 8). Both groups have a wide range of Th/U ratios ( 0 2.3 ), and it was not possible to relate these ratios to a definite magmatic origin $(>0.1)$ or a metamorphic one $(<0.1)$, according to Schaltegger et al. (1999).

\subsection{CM2 (bottom of the lower Tunuyán Conglomerate)}

Ninety-eight zircon grains were analysed by the U-Pb LA-ICPMS method, but 4 of them were excluded due to the high discordance and/ or uncertainty (Fig. 9, Tables 3 and 4). The spectra of the 94 best ages range from $14.3 \pm 0.6 \mathrm{Ma}$ to $1870 \pm 25 \mathrm{Ma}$. The main groups of ages are early Permian-Late Triassic (22\%; 236-285 Ma) with a peak at ca. 
(a) $\mathrm{CM} 2$

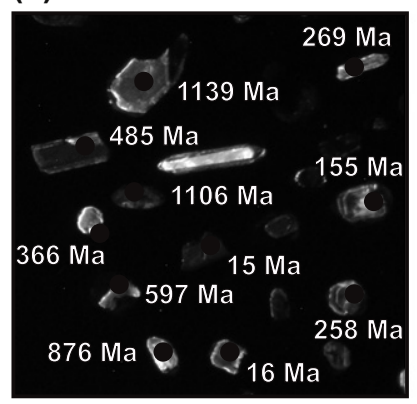

(b) $\mathrm{CM} 5$

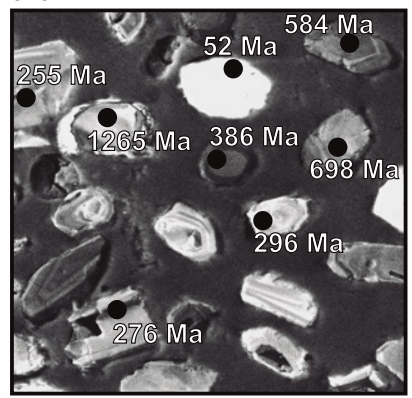

(c) 12

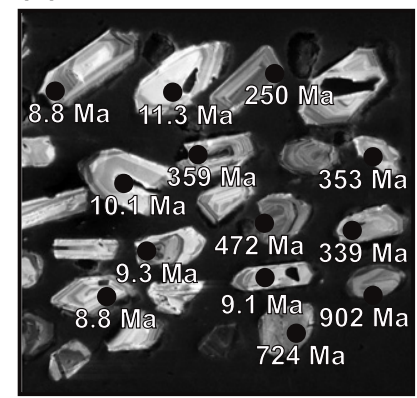

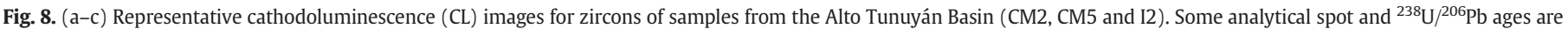
marked.

265 Ma, and middle Mesoproterozoic-early Neoproterozoic (16\%; 876$1236 \mathrm{Ma})$. Minor age groups are: 14-19 Ma (13\%; middle Miocene), 79-178 Ma (13\%; Early Jurassic-Cretaceous), 344-373 Ma (10\%; Late Devonian-early Carboniferous) and 447-519 Ma (11\%; early Cambrian-Late Ordovician). The range of detrital zircon ages also includes one Late Triassic age (post-Choiyoi; $219 \mathrm{Ma}$ ) amongst middle Neoproterozoic-early Cambrian ( $\mathrm{n}=5$; 520-650 Ma), Mesoproterozoic ( $\mathrm{n}=4 ; 1.30$ $1.46 \mathrm{Ga})$, and Paleoproterozoic $(\mathrm{n}=2 ; 1831-1870 \mathrm{Ma})$ ages.

\subsection{CM5 (top of the lower Tunuyán Conglomerate)}

A hundred zircon grains were analysed by the U-Pb LA-ICPMS method, but 4 of them were rejected due to high discordance and/or uncertainty (Fig. 9, Tables 3 and 4). Reliable ages range between $18.9 \pm 0.2 \mathrm{Ma}$ and $1705 \pm 16 \mathrm{Ma}$. Three main groups of ages exist, one between 250 and $298 \mathrm{Ma}$ (24\%; early Permian-Early Triassic) with a peak at ca. $275 \mathrm{Ma}$, another between 385 and 513 Ma (18\%; middle Cambrian-late Middle Devonian) with a peak at ca. $383 \mathrm{Ma}$, and a last group between 1007 and $1265 \mathrm{Ma}$ (15\%; middle Mesoproterozoic-early Neoproterozoic). Smaller groups have a middle Neoproterozoic-early Cambrian (10\%; 520-650 Ma) age, and one group has a Mesoproterozoic age (11\%; $1310-1527 \mathrm{Ma}$ ). There are also zircons represented by Early Jurassic-Cretaceous ( $\mathrm{n}=6 ; 111-201 \mathrm{Ma})$, Late Devonian-early Carboniferous $(\mathrm{n}=$ 7; 356-380 Ma), and Neoproterozoic ( $\mathrm{n}=4$; 685-698 Ma) age groups. Single early Miocene (18.8 Ma), Eocene (51.7 Ma) and Paleoproterozoic (1074 Ma) zircon grains are also present.

\subsection{CL9a (upper Tunuyán Conglomerate)}

A total of 101 zircons grains were dated by the U-Pb LA-ICPMS method, and only two of them were rejected due to high discordance and/or uncertainty (Fig. 9, Tables 3 and 4). The ages are constrained between $8.5 \pm 1.2 \mathrm{Ma}$ and $2622 \pm 11 \mathrm{Ma}$. The main group of ages lies between 8 and $29 \mathrm{Ma}$ (55\%; late Oligocene-Miocene) with one peak at ca. 11.2 Ma. A subordinate population is represented by early Permian-Late Triassic zircon ages (11\%, 232-292 Ma), with a peak at ca. $275 \mathrm{Ma}$. Minor groups occur between 303 and $325 \mathrm{Ma}$ ( $\mathrm{n}=6$; late Carboniferous), 383 and $417 \mathrm{Ma}$ ( $\mathrm{n}=6$; middle Cambrian-early Late Devonian), and between 913 and 1209 Ma ( $\mathrm{n}=$ 9; middle Mesoproterozoic-early Neoproterozoic). The detrital zircon age range also includes minor Early Jurassic-Cretaceous $(\mathrm{n}=3 ; 115-175 \mathrm{Ma})$, and Neoproterozoic $(\mathrm{n}=6$; 590-747 Ma) ages. A single Eocene zircon age ( $58 \mathrm{Ma}$ ), a Mesoproterozoic (1417 Ma) and one Neoarchean (2622 Ma) ages are also present.

\subsection{I2 (Ignimbrita Arroyo Chileno, lower Palomares Formation)}

In this sample 48 zircon grains were analysed by the U-Pb LA-ICPMS method and only one was excluded (Fig. 9, Tables 3 and 4). The 47 best ages lie between $8.4 \pm 0.6 \mathrm{Ma}$ and $1854 \pm 12.3 \mathrm{Ma}$, with two main peaks. The largest is at ca. $9 \mathrm{Ma}$, which comprises ages between 8.4 and 15.1 Ma (44\%; middle-late Miocene), and the other at ca. $253 \mathrm{Ma}$ with ages between 232 and 279 Ma (29\%; early Permian-Late Triassic). There are minor groups in the Early Jurassic-Cretaceous $(\mathrm{n}=2 ; 162-$ $165 \mathrm{Ma})$, Late Devonian-early Carboniferous $(\mathrm{n}=4$; 339-359 Ma), and middle Mesoproterozoic-early Neoproterozoic ( $\mathrm{n}=4$; 902$1280 \mathrm{Ma}$ ). Single ages were obtained for the middle Cambrian-early Late Devonian (472 Ma; Early Ordovician), Neoproterozoic (724 Ma) and late Paleoproterozoic (1824 Ma) age groups.

\section{Interpretation, discussion and conclusive remarks}

\subsection{Age of the basin and contemporaneous volcanism}

\subsubsection{Age of the basin}

The youngest age group, calculated from nine zircon grains of sample CM2, is $15.0 \pm 0.4 \mathrm{Ma}(\mathrm{n}=9$; error of $95 \%$ conf.; $\mathrm{MSWD}=0.88$; Table 3 and Fig. 9), indicating a middle Miocene (ca. $15 \mathrm{Ma}$ ) maximum depositional age for the lower Tunuyán Conglomerate (Fig. 9). This age, obtained close to the base of the Tunuyan Conglomerate, is coherent with the ca. $18 \mathrm{Ma}$ age of the Contreras Formation that underlies the Tunuyán Conglomerate. Therefore, the youngest obtained age of ca. 18.8 Ma in a single zircon from sample CM5 is only a maximum depositional age of the upper part of the lower Tunuyán Conglomerate. In consequence, this age will not be taken into account as it is older than the underlying Contreras Formation (ca. $18 \mathrm{Ma}$ ) and the detrital zircon age of the lower part of the Tunuyán Conglomerate. Highly constrained ages for the upper part of the basin are given by samples CL9a and I2. The youngest detrital zircon group in sample CL9a indicates an age of $11.1 \pm 0.2 \mathrm{Ma}(\mathrm{n}=39$; MSWD: 1.9; Table 3 and Fig. 9), late Miocene, as the maximum depositional age for the upper Tunuyán Conglomerate. Thus, this age and that from CM2 restrict the age of the entire unit at ca. 15 to $11 \mathrm{Ma}$ (middle to late Miocene). Andesitic lava from the middle Tunuyán Conglomerate (Fig. 9) was previously dated at $8.0 \pm 1.6 \mathrm{Ma}$ (K-Ar on a whole-rock sample, Giambiagi, 1999). However, this rock is geochemically altered with Fe-Ti oxides and chlorite, which suggests that the age is probably inaccurate. With our new data, we propose that the age of the andesitic lavas and breccias intercalated in the middle Tunuyán Conglomerate is constrained between 15 and 11 Ma. The maximum formation age of the Ignimbrita Arroyo Chileno (I2) is $9.02 \pm$ $0.23 \mathrm{Ma}(\mathrm{n}=13$; MSWD $=0.63$; Table 3$)$. This age restricts the deposition of the Palomares Formation to the late Miocene, being close to the age of the upper Tunuyán Conglomerate. The age correlations established by Giambiagi et al. (2003b) for the Butaló Formation, restrict the age of the younger deposits in the basin at about $6 \mathrm{Ma}$. Therefore, previous and new data allow us to constrain the basin between ca. 15 and $6 \mathrm{Ma}$ in age.

\subsubsection{Miocene contemporaneous volcanism}

The volcanic beds in the Alto Tunuyán Basin, the andesitic lavas and breccias in the middle Tunuyán Conglomerate, and the Ignimbrita 


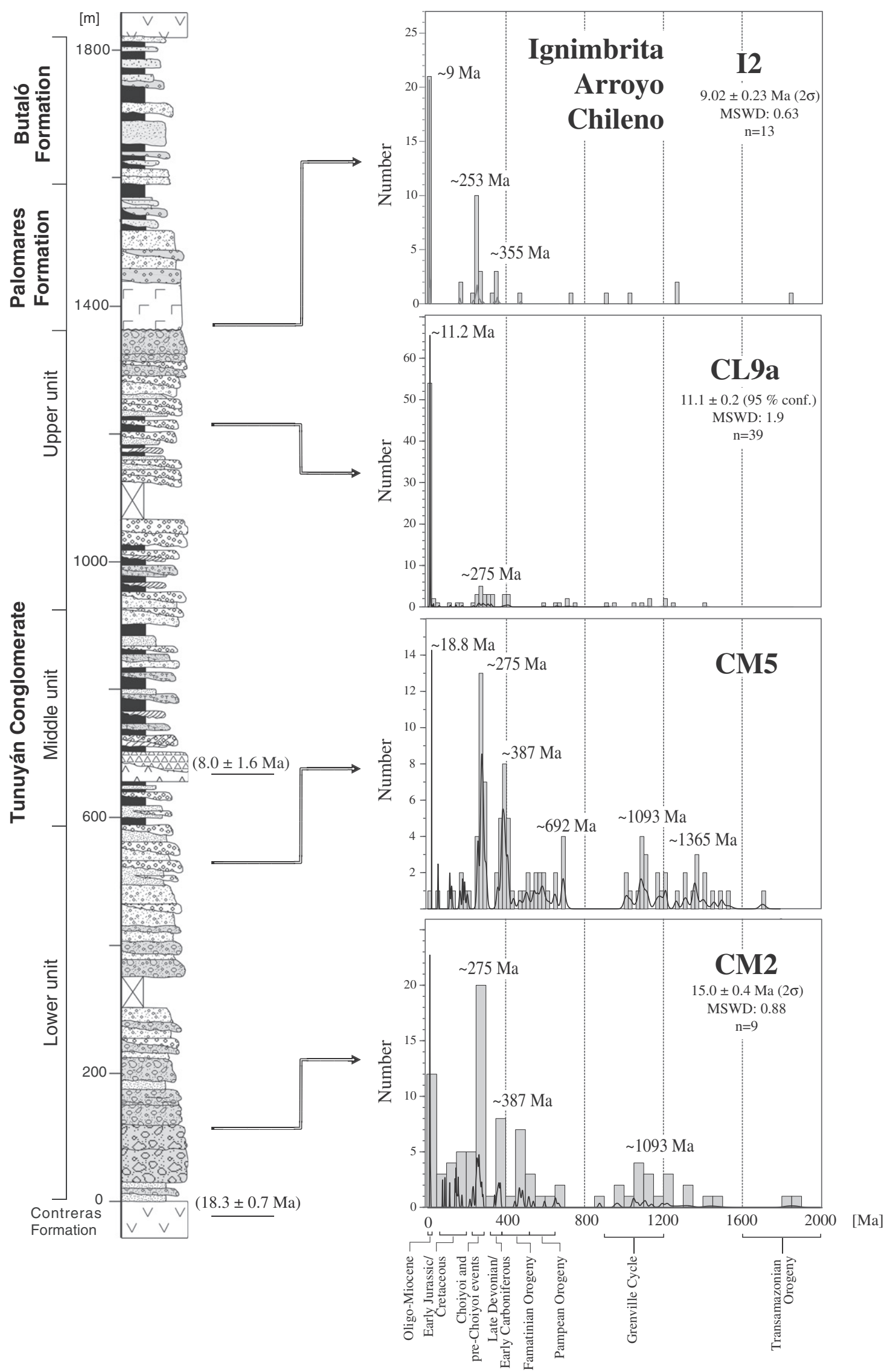

Fig. 9. Frequency histograms and relative probability plots for the detrital zircon samples from the Alto Tunuyán Basin. Symbols and lithologies as in Fig. 3. 
Table 3

Main U-Pb age pattern of dated Alto Tunuyán Basin samples. Samples are in stratigraphic order from the oldest (down) to the youngest (up).

\begin{tabular}{llllll}
\hline Sample & & Age (Ma) & $\mathrm{n}$ & MSWD & Error estim. \\
\hline $\mathrm{I} 2$ & Oldest age & $1854.0 \pm 12.3$ & 1 & - & 1 sigma \\
$n_{t}=48$ & Youngest age & $8.42 \pm 0.56$ & 2 & - & 2 sigma \\
$\mathrm{PFm}$ & Youngest main group & $9.02 \pm 0.23$ & 13 & 0.63 & 2 sigma \\
$\mathrm{CL9a}$ & Oldest age & $2622.1 \pm 11.0$ & 1 & - & 1 sigma \\
$n_{t}=101$ & Youngest age & $8.55 \pm 1.22$ & 1 & - & 1 sigma \\
$\mathrm{uT}$ & Youngest main group & $11.1 \pm 0.2$ & 39 & 1.9 & $95 \%$ conf. \\
$\mathrm{CM} 5$ & Oldest age & $1704.5 \pm 15.6$ & 1 & - & 1 sigma \\
$n_{t}=100$ & Youngest age & $18.8 \pm 0.2$ & 1 & - & 1 sigma \\
$\mathrm{IT}$ & Youngest main group & $275.5 \pm 3.0$ & 17 & 1.3 & $95 \%$ conf. \\
$\mathrm{CM} 2$ & Oldest age & $1870 \pm 25$ & 1 & - & 1 sigma \\
$n_{t}=94$ & Youngest age & $14.3 \pm 0.6$ & 1 & - & 1 sigma \\
$\mathrm{IT}$ & Youngest main group & $15.0 \pm 0.4$ & 9 & 0.88 & 2 sigma \\
\hline
\end{tabular}

IT: lower Tunuyán Conglomerate; uT: upper Tunuyán Conglomerate; PFm: Palomares Formation.

Arroyo Chileno at the base of Palomares Formation, register volcanic activity coeval with the development of the basin. The age of the andesitic lavas and breccias (ca. 15-11 Ma) and that from the Ignimbrita Arroyo Chileno (ca. $9 \mathrm{Ma}$ ) restrict this volcanism to the time interval between 15 and $9 \mathrm{Ma}$. Besides, the detrital zircons (ca. $11 \mathrm{Ma}$ ) of sample CL9a in the upper Tunuyán Conglomerate might come from the erosion of rocks related to this volcanism or associated plutonic rocks.

In the Chilean Principal Cordillera, this age range (ca. 15-9 Ma) coincides with the ages of the middle-late Miocene plutons (La Carlota, San Gabriel, La Gloria, Mesón Alto) ca. 14-9 Ma (e.g., K-Ar and Ar-Ar, Kurtz et al., 1997; U-Pb, Deckart et al., 2010). But, if these units represent the source of the $11 \mathrm{Ma}$ old detrital zircons in the Alto Tunuyán Basin, they would have needed at least a couple of million years to be exhumed and eroded in order to contribute to the basin. If that was the case, a younger age for the upper Tunuyán Conglomerate should be expected. Besides, $\mathrm{K}-\mathrm{Ar}$ ages at about 15-10 Ma have also been determined for the volca-

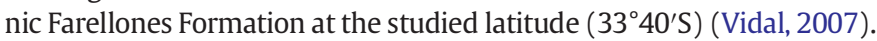
However, the rocks are very close to plutons of the same age (U-Pb ages; Deckart et al., 2010), indicating that the ages are most probably rejuvenated. Moreover, the Farellones Formation presents young $\mathrm{K}-\mathrm{Ar}$ whole-rock ages between $14.1 \pm 0.6 \mathrm{Ma}$ and $8.3 \pm 0.1 \mathrm{Ma}$ to the south (Río Cachapoal, $34^{\circ} 15^{\prime}$ S; Charrier and Munizaga, 1979). Therefore, there are no accurate data to guarantee that the andesitic lavas and breccias and the ignimbrite in the Alto Tunuyán Basin come from the volcanic Farellones Formation at the studied latitude.

On the other hand, volcanic rocks in the Frontal Cordillera (Fig. 1) (Cordillera de las Yaretas, Pérez, 2001), containing calc-alkaline volcanic breccias with a Miocene $\mathrm{K}-\mathrm{Ar}$ age of $13.5 \pm 2.1 \mathrm{Ma}$, could be related to the volcanic rocks found in the Alto Tunuyán Basin. However, the available age is not very precise and does not allow an unquestionable correlation. Nevertheless, on the eastern side of the Frontal Cordillera, at the same studied latitude (50 $\mathrm{km}$ from the Cordón del Portillo, Fig. 1c), a sandy volcanic deposit with a geochemistry and age similar to the Ignimbrita Arroyo Chileno ( $9.16 \pm 0.5 \mathrm{Ma}$, average Ar-Ar ages; Irigoyen et al., 1999, 2000) is represented by the Tobas Angostura lithology, which could represent reworked material from the same volcanic centre (on the axis of the Cordón del Portillo, Fig. 1c). Accordingly we can propose that a volcanic centre located in the Frontal Cordillera (Cordillera de las Yaretas?) triggered a westward pyroclastic flow, which would have generated the Ignimbrita Arroyo Chileno at a distance of $20 \mathrm{~km}$, and also reworked volcanic material to the east in the Cacheuta Basin (Tobas de Angostura). The thickness of the Ignimbrita Arroyo Chileno $(84 \mathrm{~m})$, the size of the pumice therein $(1-3 \mathrm{~cm})$ and the lithics at its base suggest an explosive event with a high initial potential energy, a high gas content and a big volume (Branney and Kokelaar, 2002; Troncoso, 2012). Furthermore, the presence of pinkish granite clasts included at the bottom of the Ignimbrita Arroyo Chileno, very similar to rocks of the Composite Batholith in the Frontal Cordillera (see below), supports at least a supply from the east, as has been previously proposed (e.g., Darwin, 1846; Giambiagi et al., 2003b), and a high potential energy of the pyroclastic flow (Branney and Kokelaar, 2002; Troncoso, 2012).

Thus, the available data allow us to locate the volcanic activity that generated the Ignimbrita Arroyo Chileno in the Frontal Cordillera. This was probably a volcanic center that could be correlated with the Yaretas Volcanic Complex. The andesitic lavas and breccias and the $11 \mathrm{Ma}$ detrital zircons (volcanic or plutonic) in the middle and upper Tunuyán Conglomerate could have been supplied from both the middle Miocene (ca. 14-9 Ma) volcanic or plutonic rocks from the Principal Cordillera or from those in the Frontal Cordillera. It is an interesting challenge to further study in detail the chronology of Miocene volcanic units in the Cordillera Principal and Cordillera Frontal to be able to establish the origin of these deposits.

\subsection{Source rocks}

A combination of petrographic and geochronologic data allows us to define four major source rocks for the Alto Tunuyán Basin sedimentary deposits: intermediate volcanic, acidic igneous, metamorphic and sedimentary rocks.

\subsubsection{Andesitic volcanic source}

The contribution of an andesitic volcanic source is evidenced by the concentration of Na-plagioclase and basic volcanic fragments in sandstones, showing gradual increases and decreases in the sedimentary succession (Figs. 6d, f and 7). This volcanic source predominates in the lower and middle Tunuyán Conglomerate (Fig. 6d, f), supported by higher average values of $\mathrm{P} / \mathrm{Ft}$ in these units (Fig. $6 \mathrm{~g}$ ). In the upper Tunuyán Conglomerate and the Palomares Formation, this source

Table 4

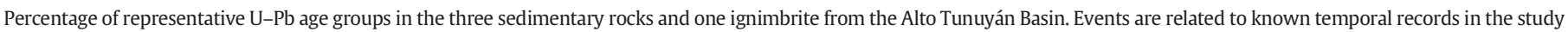
area on a local and regional-to-distal scale to demonstrate probable source areas (temporal records modified after Bahlburg et al., 2009 and references therein).

\begin{tabular}{|c|c|c|c|c|c|}
\hline \multirow[t]{2}{*}{ Age range visible in samples } & \multirow[t]{2}{*}{ Corresponding geological cycle } & \multirow{2}{*}{$\frac{\mathrm{CM} 2}{[\%]}$} & \multirow{2}{*}{$\frac{\text { CM5 }}{[\%]}$} & \multirow{2}{*}{$\frac{\text { CL9a }}{[\%]}$} & \multirow{2}{*}{$\frac{\mathrm{I} 2}{[\%]}$} \\
\hline & & & & & \\
\hline Oligo-Miocene (9-30 Ma) & & $13(n=12)$ & $1(\mathrm{n}=1)$ & $55(n=56)$ & $44(n=21)$ \\
\hline Eocene (34-56 Ma) & & - & $1(\mathrm{n}=1)$ & $1(n=1)$ & - \\
\hline Early Jurassic-Cretaceous (66-201 Ma) & & $13(\mathrm{n}=12)$ & $6(n=6)$ & $3(\mathrm{n}=3)$ & $4(\mathrm{n}=2)$ \\
\hline Late Triassic (201-237 Ma) & & $2(\mathrm{n}=2)$ & - & - & - \\
\hline Early Permian-Late Triassic (230-298 Ma) & Choiyoi and pre-Choiyoi events & $24(n=23)$ & $24(\mathrm{n}=24)$ & $11(\mathrm{n}=11)$ & $29(n=14)$ \\
\hline Late Carboniferous (298-320 Ma) & & - & - & $6(n=6)$ & - \\
\hline Late Devonian-early Carboniferous (323-382 Ma) & & $10(\mathrm{n}=9)$ & $7(\mathrm{n}=7)$ & - & $8(\mathrm{n}=4)$ \\
\hline Middle Cambrian-early Late Devonian (380-520 Ma) & Famatinian Orogeny & $11(\mathrm{n}=10)$ & $18(\mathrm{n}=18)$ & $6(n=6)$ & $2(\mathrm{n}=1)$ \\
\hline Middle Neoproterozoic-middle Cambrium (520-650 Ma) & Pampean Orogeny & $5(\mathrm{n}=5)$ & $10(\mathrm{n}=10)$ & - & - \\
\hline Neoproterozoic (541-1000 Ma) & Brazilian-Pan African Orogeny & - & $4(n=4)$ & $6(n=6)$ & $2(\mathrm{n}=1)$ \\
\hline Middle Mesoproterozoic-early Neoproterozoic (0.9-1.25 Ga) & Grenville Cycle & $16(n=15)$ & $15(\mathrm{n}=15)$ & $9(\mathrm{n}=9)$ & $8(\mathrm{n}=4)$ \\
\hline Mesoproterozoic (1.25-1.6 Ga) & & $4(n=4)$ & $11(\mathrm{n}=11)$ & $1(\mathrm{n}=1)$ & - \\
\hline Paleoproterozoic (1.6-2.2 Ga) & Transamazonian Orogeny & $2(\mathrm{n}=2)$ & $1(\mathrm{n}=1)$ & - & $2(n=1)$ \\
\hline
\end{tabular}


decreased in comparison to previous units (Fig. 6d, f, g). The sandstones have an andesitic calc-alkaline character on average (Porras et al., 2012; Porras, 2013).

Oligocene-early Miocene ages were recognized in the studied samples (Table 4). Sample CL9a (upper Tunuyán Conglomerate) presents two zircon grains of 20 and $29 \mathrm{Ma}$, and sample CM5 (lower Tunuyán Conglomerate) shows a zircon grain dated at ca. $18.8 \mathrm{Ma}$. Similar ages are found in the mainly volcanic Abanico (ca. 37-23 Ma), Farellones (ca. 23-17 Ma) and Contreras Formations (ca. $19 \mathrm{Ma}$ ) and could, therefore, represent a reworked grain from these formations. Furthermore, the Farellones Formation has a predominant calc-alkaline andesitic character that agrees with the geochemistry of the sandstones (Porras et al., 2012; Porras, 2013), supporting a major contribution from this andesitic unit to the basin, at least, for the lower and middle Tunuyán Conglomerate according to the sandstone petrography. Moreover, the variations of this volcanic source in the Tunuyan Conglomerate (Fig. 6d) area are probably related to uplift pulses of the Principal Cordillera.

\subsubsection{Acidic igneous source}

The existence of an acidic igneous source is evidenced by the content of acidic volcanic lithics, quartz and K-feldspar in sandstones throughout the entire studied succession with evident variations (Figs. 6a, e, h and 7). This association could represent a mixing between volcanic and plutonic rocks with acidic character.

Abundant quartz and acidic volcanic lithics in sandstones appear at the base of the lower and middle Tunuyán Conglomerate and gradually decrease over time. Besides, this association shows a clear upward increasing trend from the middle to the upper Tunuyán Conglomerate, followed by a decrease and again an increase from the upper Tunuyán Conglomerate up to the Butaló Formation (Fig. 6a, e). The somewhat positive correlation between the acidic volcanic lithics and the basic volcanic lithics in the lower and middle Tunuyán Conglomerate implies a similar area of supply. Contrarily, a strong negative correlation between these two kinds of volcanic fragments in the upper Tunuyán Conglomerate (Fig. 6d, e) indicates that at around $11 \mathrm{Ma}$ (boundary between middle and upper Tunuyán Conglomerate) a significant change of the supply area occurred.

On the other hand, the plutonic character of the acidic source is indicated by the almost constant and higher percentages of K-feldspar in the upper Tunuyán Conglomerate, Palomares Formation and Butaló Formation (Fig. 6h) with respect to the lower and middle Tunuyán Conglomerate, confirming a rather global change of the source areas around $11 \mathrm{Ma}$.

Furthermore, the Permo-Triassic age range (ca. 230-298 Ma, peak ca. $270 \mathrm{Ma}$ ) represents a significant population of the studied zircons, existent in all of the samples and well represented in the basal samples (CM2 and CM5), with a smaller representation in the upper samples (CL9a and I2) (Table 4, Fig. 9). These ages are similar to those from the Choiyoi Group (Fig. 1c), and therefore we relate the acidic igneous source (volcanic and plutonic) to this unit. This unit has been extensively described as representing a large magmatic event from northern Chile to Central Argentina because of the diversity of ages obtained from it (Table 4) (e.g., Kleiman and Japas, 2009; Hervé et al., 2014). Most of the zircon ages obtained in this study are in accordance with the 230-270 Ma range of ages compiled for the Choiyoi Group in the Argentinean Frontal Cordillera at the latitude of Mendoza (Martínez and Giambiagi, 2010, and references therein). Besides, a $266 \pm 6$ Ma age (K-Ar, sanidine, Martínez and Giambiagi, 2010) was obtained on a vitreous rhyolitic ignimbrite in the middle section of this unit at the studied latitude. Other geochronological studies (e.g., Polanski, 1964; Orme and Atherton, 1999; Gregori and Benedini, 2013) assigned a similar age to the plutons from the Frontal Cordillera Composite Batholith (Cordón del Portillo Pluton) (ca. 262-276 Ma) (Fig. 1c), which has been related to the Choiyoi Group and, thus, included in the Choiyoi Magmatic Province. Furthermore, the range of the older Permian ages of the studied detrital zircons are correlated to that from the syntectonic plutons of the San Rafael contractional event (ca. 276-284 Ma) registered south of the studied region (e.g., Kleiman and Japas, 2009; Gregori and Benedini, 2013). Although the age range between 284 and 298 Ma has been assigned to the magmatic Choiyoi Province in northern Chile (Hervé et al., 2014), at these latitudes they are not registered. Therefore, considering the volcanic Choiyoi Group, the Frontal Cordillera Composite Batholith and the San Rafael block plutons as part of the Choiyoi Magmatic Province, we can consider this magmatic province as the origin for the acidic igneous material and Permo-Triassic detrital zircons of 230-284 Ma age recognized in the deposits of the Alto Tunuyán Basin. On the other hand, a preliminary geochronological study on one granitic clast taken from the Ignimbrita Arroyo Chileno (see above) by our working group (not published) indicates an age between ca. 250 and $350 \mathrm{Ma}$. Although the ages are not perfectly suited for the age of the batholith, they suggest a possible provenance from the Choiyoi Magmatic Province. The contribution of this material might have begun slowly at about $11 \mathrm{Ma}$ considering the increase in K-feldspar from the base of the upper Tunuyán Conglomerate.

\subsubsection{Metamorphic source}

This source is scarce ( $<2 \%$ in sandstones) and is evidenced by the presence of metamorphic lithics (Fig. 6j). In the lower Tunuyán Conglomerate this lithic tracer is absent and two notable increases were recognized at the bottom and the top of the middle Tunuyan Conglomerate and at the limit between the Tunuyan Conglomerate and Palomares Formation (Fig. 6j). The increase of this lithic in the middle Tunuyán Conglomerate correlates with the abundance of polycrystalline quartz (Fig. 6h, j), suggesting that this detrital quartz came from a metamorphic rock. Furthermore, the metamorphic lithics show a slight correlation with the K-feldspar indicating a single/same area of supply for the metamorphic and acidic igneous material in the samples.

On the other hand, two main groups of old ages were recognized in the studied detrital zircons, mainly in lowest unit of the Alto Tunuyán Basin: a middle Mesoproterozoic-early Neoproterozoic age (ca. 900$1200 \mathrm{Ma}$, peak ca. $1093 \mathrm{Ma}$ ), and another middle Cambrian-early Late Devonian age (ca. 380-520 Ma; $\leq 29 \%$ ) (Table 4). Furthermore, other minor groups of Paleo-Mesoproterozoic (1.25-2.2 Ga), middle Neoproterozoic-middle Cambrian (520-1000 Ma), and Late Devonian-early Carboniferous (323-382 Ma) ages were recognized (Table 4). Proterozoic ages have been reported in the metamorphic rocks from the Guarguaráz Complex in the Cordón del Portillo (e.g., Polanski, 1964; Caminos, 1979; Ramos et al., 2000). This complex includes gneisses dated at $1069 \pm 36 \mathrm{Ma}, 1081 \pm 45 \mathrm{Ma}$ (zircon, U-Pb, Ramos and Basei, 1997) and 0.94-1.46 Ga (predominant maximum at $1.09 \mathrm{Ga}$, zircon, U-Pb, Willner et al., 2008). Additionally, Neoproterozoic to early Carboniferous ages for the rocks of the Guarguaráz Complex have also been reported: 330-577 Ma (model age, Sm-Nd, amphibolites and diabases), $353 \pm 1 \mathrm{Ma}$ (Ar-Ar, white mica in metapelites), $362 \pm 15 \mathrm{Ma}$ (K-Ar), $375 \pm 34 \mathrm{Ma}$ (Rb-Sr, schists and amphibolites), $390 \pm 2 \mathrm{Ma}$ (Lu-Hf, average age in garnets from metapelites and metabasites), $430 \pm 5 \mathrm{Ma}$ (K-Ar), $500 \pm 50 \mathrm{Ma}(\mathrm{Rb}-\mathrm{Sr}), 508 \pm$ $30 \mathrm{Ma}$ (K-Ar), $555 \pm 8 \mathrm{Ma}(\mathrm{U}-\mathrm{Pb})$ and $581 \pm 8 \mathrm{Ma}(\mathrm{U}-\mathrm{Pb})$ (Caminos, 1979; Ramos and Basei, 1997; Basei et al., 1998; Willner et al., 2008, 2011). It has been proposed that the Proterozoic ages in the Guaguaráz Complex could represent part of the Chilenia Alloctonous Block (Grenvillian Cycle, e.g., Ramos, 2009) on which is superimposed posterior phases (Neoproterozoic to Devonian) of deformation and metamorphism (Pampean and Famatinian Orogenies, Ramos and Basei, 1997).

On the other hand, Mesoproterozoic ages have been reported in the Cuyania and Famatina Basement Alloctonous Blocks (ca. 1-1.2 Ga) (Fig. 10), east of the Alto Tunuyán Basin (e.g., Ramos, 2009, and references therein). Similarly, late Cambrian-Ordovician ages (470$490 \mathrm{Ma}$ ) are found in the Famatina Alloctonous Block and in the Famatinian Magmatic Arc located between the Precordillera and Pampean Ranges (Figs. 1 and 10) (e.g., Ramos 2009). Nevertheless, these 
areas are very far away to the east of the basin (Giambiagi et al., 2003b) (Fig. 10).

Thus, considering the proximity, the source of metamorphic fragments and Proterozoic/early Carboniferous ages of detrital zircons included in sandstones of the Alto Tunuyán Basin probably corresponds to metamorphic rocks from the Guarguaráz Complex in the Frontal Cordillera (Cordón del Portillo and Cordón del Plata, Fig. 1c), which could have supplied them directly or were recycled in younger units (see below).

Based on our analysis on the sandstone petrography, the metamorphic contribution is only significant at the base of the middle Tunuyán Conglomerate and at the contact between the upper Tunuyán Conglomerate and the Palomares Formation. Giambiagi et al. (2003b), based on the clast-count of conglomerates, showed that the metamorphic material is more significant in the lower Palomares Formation, which is supported in part by the sandstone petrography. The difference could be explained by the fact that the sandstones can register a higher diversity of source rocks than the conglomerates. Meanwhile, the Proterozoic/early Carboniferous ages in detrital zircons indicate that this source was more significant in the lower Tunuyán Conglomerate, representing an early erosion of metamorphic rocks or a recycling process (see below).

\subsubsection{Sedimentary source}

The sedimentary source represented in sandstones is scarce $(\leq 10 \%)$ and is evidenced by sedimentary lithics (Fig. 6k) in the samples, indicating a contribution from sandstones/siltstones and limestones. Various peaks and progressive decreases of sedimentary lithics are recognized in the Tunuyán Conglomerate (Fig. 6k). These variations in the contribution of sedimentary lithics point to uplift pulses of the source area.

On the other hand, Mesozoic ages of zircons were identified and can be grouped into two small populations (Table 4), Cretaceous-Early Jurassic (66-201 Ma; s13\%) and Late Triassic (201-235 Ma; 4\%, CM2) more significant in the lower Tunuyán Conglomerate. Triassic-Cretaceous rocks are recognized in the Mesozoic formations of the Principal Cordillera (e.g., Mendoza Group, and Río Colina, Tordillo and Colimapu Formations, Fig. 2) (e.g., Giambiagi, 1999, 2000; Tunik, 2003; Charrier et al., 2007, and references therein), consistent with the ages of the detrital zircons of the Alto Tunuyán Basin (Fig. 1). However, so far there has been no systematic published geochronological study of zircons in these Mesozoic units. This source is well supported by the sedimentary clasts of conglomerates ( $10 \%$ ) recognized mainly in the lower Tunuyán Conglomerate (between 200 and $600 \mathrm{~m}$ ) (Giambiagi, 1999, 2000; Giambiagi et al., 2003b). However, it is important to note that this source, being well represented in the sandstones and conglomerates of the Tunuyán Conglomerate, is not abundantly represented in the studied detrital zircons. We propose that its low representation is due to the nature of Mesozoic sedimentary rocks that contain few zircons.

Therefore, the sedimentary lithics and detrital zircons from the studied sandstones clearly show that the Mesozoic sedimentary rocks of the Principal Cordillera were source rocks for the Alto Tunuyán Basin and contributed to it by pulses from the beginning.

\subsubsection{Other unclear sources}

Late Carboniferous (298-320 Ma) ages of detrital zircons were found only in the upper Tunuyán Conglomerate (6\%, CL9a). Granitic intrusions affecting the Guarguaráz Complex present similar ages (348 \pm 35 to $337 \pm 15 \mathrm{Ma}$, Caminos, 1979), that Willner et al. (2011) restrict to 290-353 Ma based on the analysis of Ar-Ar in metapelites and FTages (353 \pm 1 Ma in white mica of metapelites and $284 \pm 19 \mathrm{Ma}$ and $295 \pm 18 \mathrm{Ma}$, fission tracks on zircons). Late Carboniferous ages were also reported for the La Plata Formation (Caminos, 1979), which overlies the Guarguaráz Complex. Furthermore, zircons of late Carboniferous age have been reported in Paleozoic units of the Coastal Cordillera of central Chile (ca. 300-320 Ma, U-Pb, Deckart et al., 2014), but they seem to be too far away to explain their influence in the Alto Tunuyán Basin.

\subsection{Paleorelief vs. recycling}

The previous model of basin evolution (Giambiagi et al., 2003b) based on the clast-count in conglomerates and paleocurrents indicated

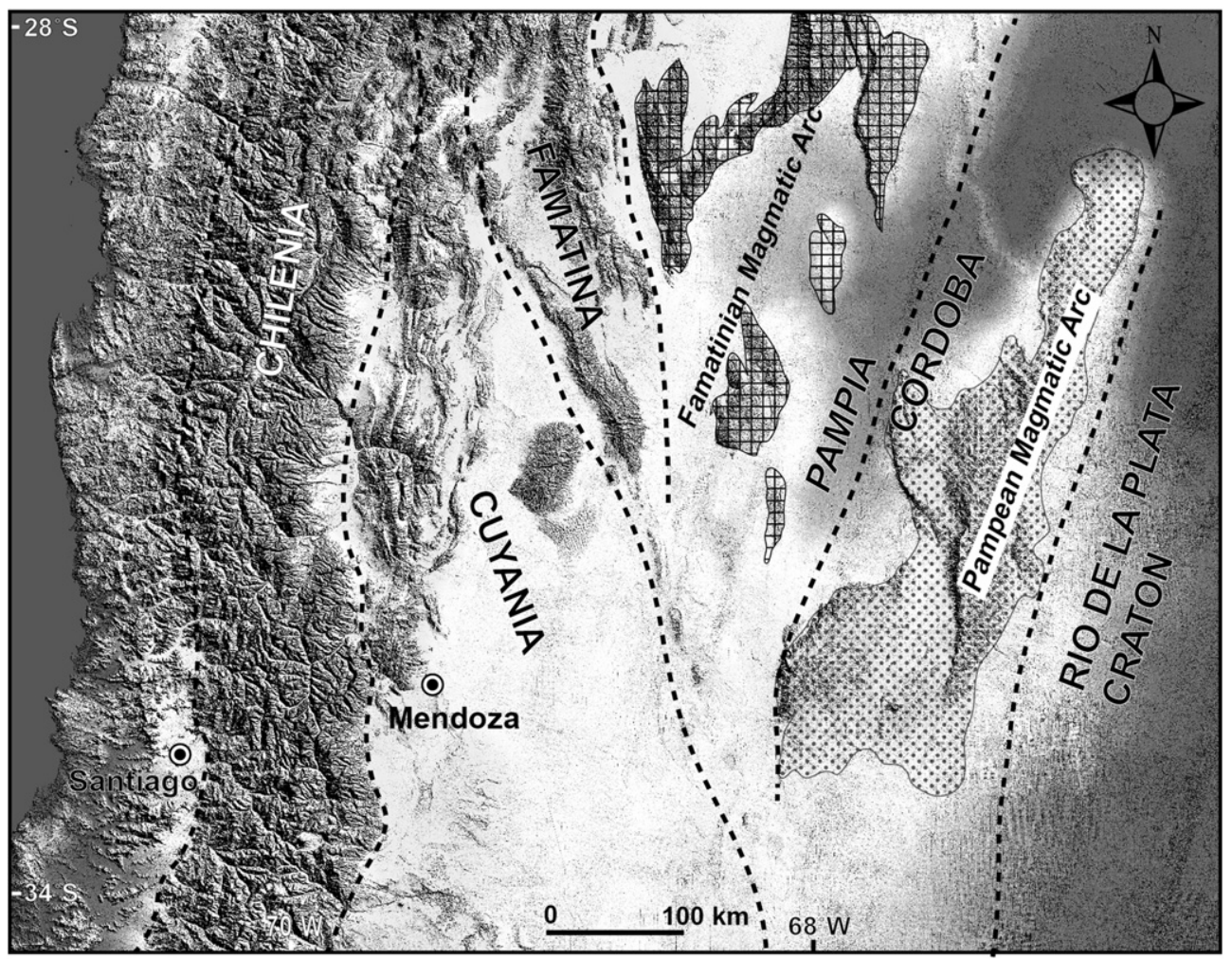

Fig. 10. Map of tectonostratigraphic alloctonous blocks of central Chile and Argentina. The approximate position of sutures is shown (based on Ramos, 2009). 
a contribution from the Frontal Cordillera only for the last period of basin development ( $<9 \mathrm{Ma}$ ). For the first period of the basin (ca. 15$9 \mathrm{Ma}$ ), corresponding to the Tunuyán Conglomerate, these authors recognized a supply area located to the west. However, the detrital zircons in the herein studied sandstones record both Mesozoic-Cenozoic ages and Permo-Triassic and Proterozoic/early Carboniferous ages in the Tunuyán Conglomerate (Figs. 6 and 9). The Permo-Triassic material is related to the Choiyoi Magmatic Province and the Proterozoic/early Carboniferous of the Guarguaráz Complex in the Frontal Cordillera at the present time, respectively.

There are two possible explanations for this record. One explanation is that the detrital zircons correspond to recycled material within the Mesozoic sedimentary units. The best-studied Mesozoic unit that could contain this recycled material is the Tordillo Formation in Argentina and its equivalent in Chile, the Río Damas Formation. To the south $\left(>35^{\circ} \mathrm{S}\right.$ latitude), the Tordillo Formation shows a main population of Jurassic age (149-200 Ma) and subordinate Middle Triassic, Permo-Triassic and late Carboniferous ages (Mescua et al., 2008; Spalletti et al., 2008; Tapia et al., 2014; Naipauer et al., 2015). Additionally, recent studies have shown that there is a single Jurassic population of $\mathrm{U}-\mathrm{Pb}$ zircon ages belonging to the Río Damas Formation, just west of the studied area $\left(33^{\circ} 50^{\prime} \mathrm{S}\right.$ ) (ca. $151 \mathrm{Ma}$; Aguirre et al., 2009; ca. $152 \mathrm{Ma}$, Tapia et al., 2014). An argument that supports a hypothesis of recycling is the good correlation between the concentrations of older detrital zircons in the studied samples (Permo-Triassic and Proterozoic/early Carboniferous), which suggests a common source. In addition, recent studies in Jurassic sedimentary basins further north in Chile show detrital zircons of the same old ages (Oliveros et al., 2012), suggesting this as a reasonable option.

Another explanation for the presence of Proterozoic/early Carboniferous and Permo-Triassic detrital zircons at 15-9 Ma in the Alto Tunuyán Basin is the existence of paleorelief in the Frontal Cordillera. This paleorelief could be assigned to (1) an underdeveloped peripheral bulge, able to provide detritus at the beginning of basin formation, as had been suggested in the model of Giambiagi et al. (2003b); or (2) an earlier uplift of the Frontal Cordillera, as recently proposed for the Cordón del Plata, $50 \mathrm{~km}$ to the north of the Cordón del Portillo, based on thermochronological studies (Hoke et al., 2015). This last proposal suggests an even older uplift at $\sim 25 \mathrm{Ma}$ in the north, and is also supported by a provenance study on the Miocene Cacheuta Foreland Basin, which shows a supply from the Choiyoi Magmatic Province based on a clast-count in conglomerates (Buelow et al., 2014). However, in the Alto Tunuyán Basin, this supply from the east was neither registered in the clast-count of conglomerates nor by paleocurrents, which show and support in fact a supply from the west (Giambiagi et al., 2003b) for the first stage of the Alto Tunuyán Basin (Tunuyán Conglomerate).

Thus, we propose that north and south of $33^{\circ} \mathrm{S}$, the foreland and intermontane basins registered a different timing of Frontal Cordillera uplift, being older in the north than in the south, and that a recycling process in the ATFB is the most appropriate explanation for the old detrital zircons at the first stage of the Alto Tunuyán Basin. More studies of detrital zircons from Mesozoic units are needed in the Cordillera Principal to confirm this proposition.

\subsection{Contribution to the provenance model for the Alto Tunuyán Basin}

From the data (Figs. 6, 7 and 9) and discussion presented above, the new data represent a complement to the provenance model for the Alto Tunuyán Basin (Fig. 11) and therefore are a contribution to our knowledge of the chronology of the Miocene Andean orogeny of central Chile and Argentina. Our data recognized the andesitic volcanic Farellones Formation from the Principal Cordillera as possibly a main contributor to the Alto Tunuyán Basin, and also support the input from Mesozoic sedimentary rocks, as proposed by previous authors (e.g., Giambiagi et al., 2003b). In addition, our data identified three main stages in the Tunuyán Conglomerate: ca. $15 \mathrm{Ma}$, ca. 15-11 Ma and ca. 11-9 Ma.
These stages are defined by progressions between andesitic and acidic igneous end-member sources, with a slightly positive correlation in the lower and middle Tunuyán Conglomerate and a negative correlation in the upper Tunuyán Conglomerate (Fig. 6d, e). The andesitic source corresponds to the Farellones Formation, which would have contributed to the basin by pulses visible in the Tunuyán Conglomerate; these pulses being associated probably with uplift pulses of the Principal Cordillera. The acidic igneous end-member should correspond to the Permo-Triassic Choiyoi Magmatic Province. This Permo-Triassic source associated with Proterozoic/early Carboniferous material (Guarguaráz Complex) could correspond to recycled material within the Mesozoic units or else to a direct supply from a paleoreflief at the current position of the Frontal Cordillera, since the middle Miocene (ca. $15 \mathrm{Ma}$ ). In any case, there are not enough data to prove the possibility that the Proterozoic-Triassic material corresponds to recycled rocks within the Mesozoic units or to find paleocurrents demonstrating a supply from the eastern border of the Alto Tunuyán Basin.

The andesitic lavas and breccias in the Tunuyán Conglomerate and the Ignimbrita Arroyo Chileno in the Palomares Formation recorded young volcanism contemporary with sedimentation in the Alto Tunuyán Basin, between ca. 15 and $9 \mathrm{Ma}$. Additionally, detrital zircons in a bed of the upper Tunuyán Conglomerate show a contribution to the basin from an igneous source of ca. $11 \mathrm{Ma}$. The supply area for this igneous products is uncertain; published data and those supplied by this study indicate a provenance from the east (Frontal Cordillera) for the Ignimbrita Arroyo Chileno, but they are not conclusive to establish if the supply for the andesitic lavas and breccias and the 11 Ma detrital zircons in the middle and upper Tunuyán Conglomerate could derive from the Principal Cordillera (Farellones Formation?) or the Frontal Cordillera (Yaretas Volcanic Complex?).

Furthermore, U-Pb ages on detrital zircons allow us to define a more accurate age for the basin. The younger age at the base of the lower Tunuyán Conglomerate and stratigraphic relationships restrict the beginning of the basin to ca. $15 \mathrm{Ma}$, slightly younger than previously proposed. Furthermore, the andesitic lavas and breccias close to the limit between the lower and middle Tunuyán Conglomerate is constrained to an age between ca. 15 and $11 \mathrm{Ma}$. The top of the upper Tunuyán Conglomerate has a maximum age of ca. $11 \mathrm{Ma}$, and the basal age of the Palomares Formation is well constrained at ca. 9 Ma by the Ignimbrita Arroyo Chileno.

\section{Acknowledgements}

The authors acknowledge financing by Project FONDECYT 1090165 , to Luisa Pinto. Major funding was obtained from the IGCP-586Y Project that supported field campaigns and scientific meetings that helped with interpretations of the published data. We also appreciate the support of the Departamento de Geología at the Universidad de Chile. We thank Victor Valencia (Valencia Geoservice) and Luigi Solari (UNAM) for the analytical data and technical assistance, which made a huge contribution to this study. Important scientific contributions were received from collaboration and discussion with Reynaldo Charrier and Felipe Tapia (Universidad de Chile). Reviews from Harriet Rawson (University of Oxford), Monserrat Cascante, Jacobus Le Roux, Marcelo Farías and Reynaldo Charrier (Universidad de Chile) and two anonymous reviewers helped to improve the final manuscript. Finally, we appreciate the technical assistance of Juan Vargas (University of Chile) and the muleteers of Manzano Histórico (Argentina).

\section{Appendix A. Supplementary data}

Supplementary material: $\mathrm{U}-\mathrm{Pb}$ (LA-ICPMS) age measurements of zircon grains are available at doi 10.1016/j.tecto.2016.09.034. 

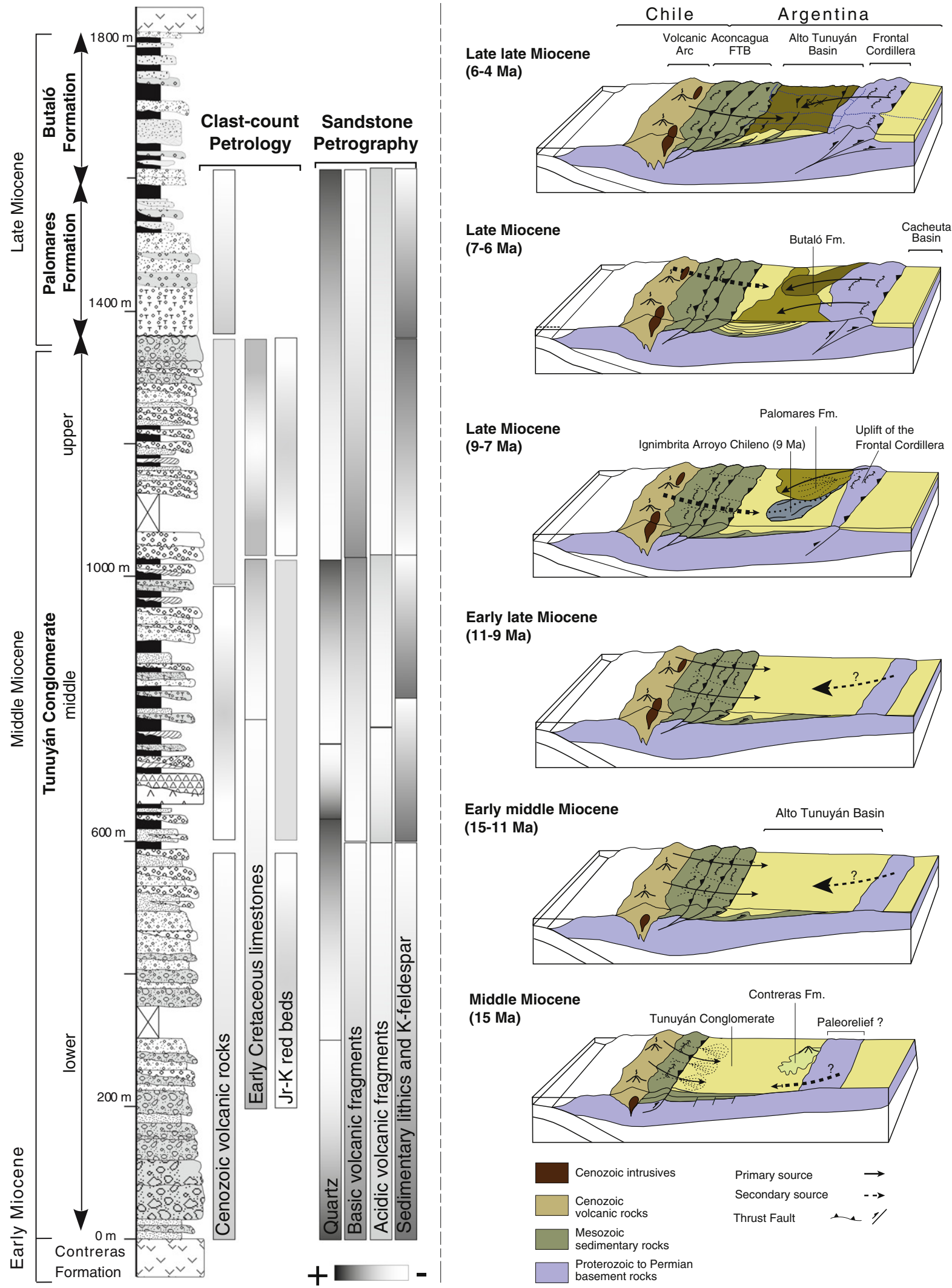

Early late Miocene

(11-9 Ma)

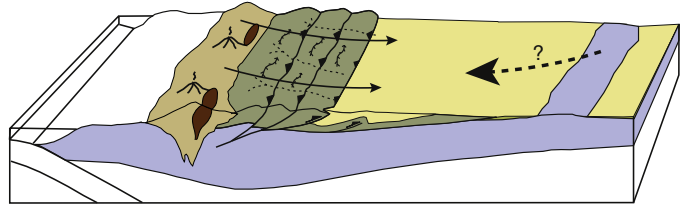

Early middle Miocene (15-11 Ma)

Alto Tunuyán Basin

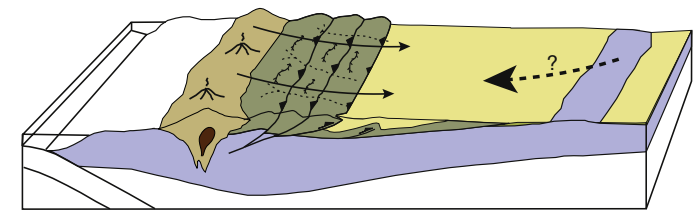

Middle Miocene

Contreras Fm.

(15 Ma)

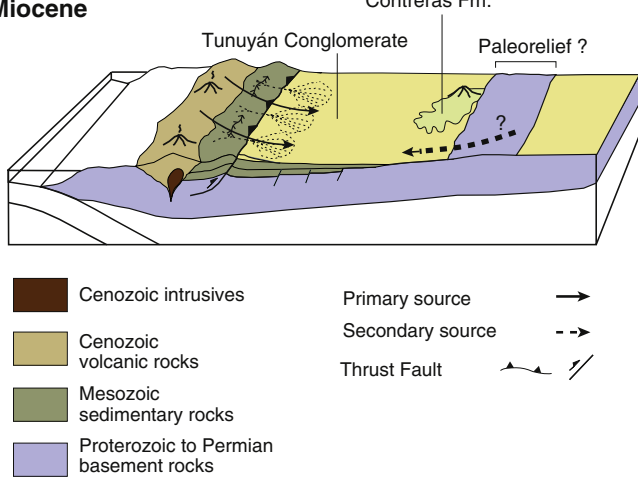

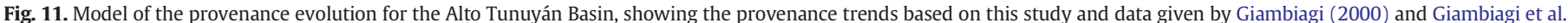
(2003b). Symbols and lithologies in the stratigraphic column as in Fig. 3. 


\section{References}

Aguirre, L., Calderón, S., Vergara, M., Oliveros, V., Morata, D., Belmar, M., 2009. Edades isotópicas de rocas de los valles Volcán y Tinguiririca, Chile central. XII Congreso Geológico Chileno, Santiago, Servicio Nacional de Geología y Minería. Actas S8-001 (digital) (4 p).

Alarcón, P., Pinto, L., 2015. Neogene erosion of the Andean Cordillera in the flat-slab segment as indicated by petrography and whole-rock geochemistry from the Manantiales Foreland Basin $\left(32^{\circ}-32^{\circ} 30^{\prime}\right.$ S). Tectonophysics 639, 1-22. http://dx.doi. org/10.1016/j.tecto.2014.11.001.

Alvarado, P., Beck, S., Zandt, G., 2007. Crustal structure of the south-central Andes Cordillera and backarc region from regional waveform modeling. Geophys. J. Int. 170, 858-875.

Álvarez, P.P., Ramos, V.A., 1999. The Mercedario rift system in the Principal Cordillera of Argentina and Chile ( $\left.32^{\circ} \mathrm{S}\right)$. J. S. Am. Earth Sci. 12, 17-31.

Álvarez, P.P., Aguirre-Urreta, M.B., Godoy, E., Ramos, V.A., 1997. Estratigrafía del Jurásico de la Cordillera Principal de Argentina y Chile $\left(33^{\circ} 45^{\prime}-34^{\circ} 00^{\prime} \mathrm{LS}\right)$. Vol. 1. VIII Congreso Geológico Chileno, Antofagasta, pp. 425-429.

Álvarez, P.P., Godoy, E., Giambiagi, L., 1999. Estratigrafía de la Alta Cordillera de Chile Cen-

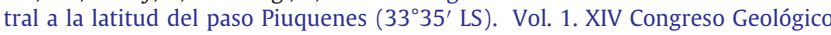
Argentino, Salta, Argentina, p. 55.

Álvarez, P.P., Ramos, V.A., Giambiagi, L.B., Godoy, E., 2000. Relationships Between Different Depocenters of Triassic - Jurassic Rift Systems in the Main Andes of Argentina and Chile. XXIII Geological International Congress, Actas in CD, Río de Janeiro.

Bahlburg, H., Vervoort, J.D., Andrew Du Frane, S., Bock, B., Augustsson, C., Reimann, C., 2009. Timing of crust formation and recycling in accretionary orogens: insights learned from the western margin of South America. Earth Sci. Rev. 97, 215-241.

Baranzangi, M., Isacks, B.L., 1976. Spatial distribution of earthquakes and subduction of the Nazca plate beneath South America. Geology 4, 686-692.

Basei, M., Ramos, V.A., Vujovich, G.I., Poma, S., 1998. El basamento metamórfico de la Cordillera Frontal: nuevos datos geocronológicos e isotópicos. X Congreso Latinoamericano de Geología and VI Congreso Nacional de Geología Económica, Buenos Aires. Actas II. pp. 412-417.

Basu, G.G., 1985. Influence of climate and relief on compositions of sands released at source areas. In: Zuffa, G.G. (Ed.), Provenance of Arenites, pp. 1-18 (Holland, Reidel).

Bhatia, M., 1983. Plate tectonics and geochemical composition of sandstones. J. Geol. 91, 611-627.

Branney, M.J., Kokelaar, P., 2002. Pyroclastic density currents and the sedimentation of ignimbrites. Geol. Soc. Lond. Mem. 27.

Buelow, E.K., Suriano, J., Mahoney, J.B., Mescua, J., Giambiagi, L., Kimbrough, D.L., 2014. Evolution of the Neogene Cacheuta Basin: A Record of Orogenic Exhumation and Basin Inversion in the South Central Andes. Geological Society of America, Annual Meeting, Paper. Vols. 143-10 p. T126 (Vancouver, 19-24 October 2014).

Cahill, T., Isacks, B.L., 1992. Seismicity and shape of the subducted Nazca Plate. J. Geophys. Res. 97, 17503-17529.

Caminos, R., 1979. Cordillera frontal. In: Turner, J.C.M. (Ed.), Geología Regional Argentina Vol. 1. Academia Nacional de Ciencias, pp. 397-453.

Cegarra, M., Ramos, V.A., 1996. La faja plegada y corrida del Aconcagua. In: Ramos, V.A., et al. (Eds.), Geología de la región del Aconcagua, provincias de San Juan y Mendoza 24. Subsecretaría de Minería de la Nación, Dirección Nacional del Servicio Geológico, Buenos Aires, Anales, pp. 387-422 14.

Chang, Z., Vervoort, J.D., Knaack, C., McClelland, W.C., 2006. U-Pb dating of zircon by LAICP-MS. Geochem. Geophy. GeosysT. 7 (5), 1-14.

Charrier, R., 1981. Mesozoic and Cenozoic stratigraphy of the Central Argentinian-Chilean Andes $\left(32^{\circ}-35^{\circ} \mathrm{S}\right)$ and chronology of their tectonic evolution. Zentralblatt für Geologie und Paläontologie, Stuttgart, Part I. 1 (3), 344-355.

Charrier, R., Munizaga, F., 1979. Edades K-Ar de volcanitas cenozoicas del sector cordillerano del río Cachapoal, Chile ( $34^{\circ} 15^{\prime}$ lat. S). Rev. Geol. Chile 7, 41-51.

Charrier, R., Baeza, O., Elgueta, S., Flynn, J., Gans, R., Kay, S., Muñoz, N., Wyss, A., Zurita, E. 2002. Evidence for Cenozoic extensional basin development and tectonic inversion south of the flat-slab segment, southern Central Andes, Chile $\left(33^{\circ}-36^{\circ} \mathrm{S}\right)$. J. S. Am. Earth Sci. 15, 117-139.

Charrier, R., Pinto, L., Rodríguez, M.P., 2007. Tectonostratigraphic evolution of the Andean Orogen in Chile. In: Moreno, T., Gibbons, W. (Eds.), The Geology of Chile. Soc. Spec. Publ, Geol, pp. 21-113.

Cloos, M., Shreve, R.L., 1996. Shear zone thickness and the seismicity of Chilean- and Mariana-type subduction zones. Geology 24 (2), 107-110.

Darwin, Ch.R., 1846. Geological Observation in South America. Being the Third Part of the Geology of Voyage of Beagle, during the Years 1832 to 1836. Smith Elder and Co. (Eds.), (279 p, London).

Deckart, K., Clark, A.H., Aguilar, C., Vargas, R., 2005. Magmatic and hydrothermal chronology of the supergiant Río Blanco porphyry copper deposit, Central Chile: implications of an integrated U-Pb and ${ }^{40} \mathrm{Ar}-{ }^{39} \mathrm{Ar}$ database. Econ. Geol. 100 (5), 905-934.

Deckart, K., Godoy, E., Bertens, A., Jerez, D., Saeed, A., 2010. Barren Miocene granitoids in the central Andean metalogenic belt, Chile: geochemistry and $\mathrm{Nd}-\mathrm{Hf}$ and $\mathrm{U}-\mathrm{Pb}$ isotope systematic. Andean Geol. 37 (1), 1-31.

Deckart, K., Hervé, F., Fanning, M., Ramírez, V., Calderón, M., Godoy, E., 2014. Geocronología $\mathrm{U}-\mathrm{Pb}$ e isótopos de $\mathrm{Hf}-\mathrm{O}$ en circones del batolito de la costa Pensilvaniana. Chile. Andean Geol. 41 (1), 49-82. http://dx.doi.org/10.5027/andgeoV41n1-a03.

Dewey, J.F., Bird, J.M., 1970. Mountain belts and the new global tectonics. J. Geophys. Res. 75 (14), 2625-2647.

Dickinson, W., 1970. Interpreting detrital modes of graywacke and arkose. J. Sediment. Petrol. 40, 695-707.

Dickinson, W.R., 1985. Interpreting Provenance Relations from Detrital Modes of Sandstones. In: Zuffa, G.G. (Ed.), Provenance of Arenites. Reidel Publ, Dordrecht, pp. 333-361.
Dickinson, W.R., Gehrels, G.E., 2003. U-Pb ages of detrital zircons from Permian and Jurassic Eolianite sandstones of the Colorado plateau, USA: paleogeographic implications. Sediment. Geol. 163, 29-66.

Dickinson, W.R., Beard, L.S., Brakenridge, G.R., Erjavee, J.R., Ferguson, R.C., Inman, K.F. 1983. Provenance of north American Phanerozoic sandstones in relation to plate tectonic setting. Geol. Soc. Am. Bull. 94, 222-235.

Fock, A., Charrier, R., Farías, M., Muñoz, M., 2006. Fallas de vergencia oeste en la Cordillera Principal de Chile central: inversión de la Cuenca de Abanico $\left(33^{\circ}-34^{\circ} \mathrm{S}\right)$. Rev. Asoc. Geol. Argent. 6, 48-55.

Folk, R., Andrews, P., Lewis, D., 1970. Detrital sedimentary rock classification and nomenclature for use in New Zealand. N. Z. J. Geol. Geophys. 13, 937-968.

Fuentes, F., Vergara, M., Aguirre, L., Féraud, G., 2002. Relaciones de contacto de unidades volcánicas terciarias de los Andes de Chile central $\left(33^{\circ} \mathrm{S}\right)$ : una reinterpretación sobre la base de dataciones ${ }^{40} \mathrm{Ar} /{ }^{39} \mathrm{Ar}$. Rev. Geol. Chile 29 (2), 207-225.

Gansser, A., 1973. Facts and theories on the Andes. J. Geol. Soc. Lond. 129, 93-131.

Giambiagi, L., 1999. Los depósitos neógenos de la región del río Palomares, Cordillera Principal de Mendoza. Rev. Asoc. Geol. Argent. 54 (1), 47-59.

Giambiagi, L., Estudio de La evolución tectónica de la Cordillera Principal de Mendoza en el sector comprendido entre los $33^{\circ} 30^{\prime}$ y los $33^{\circ} 45^{\prime}$ Latitud Sur (Ph.D. thesis), Universidad de Buenos Aires (255 p).

Giambiagi, L., Ramos, V.A., 2002. Structural evolution of the Andes between $33^{\circ} 30^{\prime}$ and $33^{\circ} 45^{\prime} \mathrm{S}$, above the transition zone between the flat and normal subduction segment, Argentina and Chile. J. S. Am. Earth Sci. 15, 99-114.

Giambiagi, L., Tunik, M., Ghiglione, M., 2001. Cenozoic tectonic evolution of the Alto Tunuyán foreland basin above the transition zone between the flat and normal subduction segment $\left(33^{\circ}-34^{\circ} \mathrm{S}\right)$, western Argentina. J. S. Am. Earth Sci. 14, 707-724.

Giambiagi, L.B., Álvarez, P.P., Godoy, E., Ramos, V.A., 2003a. The control of pre-existing extensional structures in the evolution of the southern sector of the Aconcagua fold and thrust belt. Tectonophysics 369, 1-19.

Giambiagi, L.B., Ramos, V.A., Godoy, E., Álvarez, P.P., Orts, S., 2003b. Cenozoic deformation and tectonic style of the Andes, between $33^{\circ}$ and $34^{\circ}$ South Latitude. Tectonics 22 (4) 1041. http://dx.doi.org/10.1029/2001TC001354.

Godoy, E., 1993. El Caloviano del Estero Yeguas Muertas, Río Yeso del Maipo, Chile: implicancias tectónicas y paleogeográficas. XII Congreso Geológico Argentino y II Congreso de Exploración de Hidrocarburos, Mendoza. Vol. 1, pp. 104-107.

Godoy, E., 1998. Intrusivos sintectónicos entre los ríos Aconcagua y Cachapoal, Andes de Chile Central. X Congreso Latinoamericano de Geología and VI Congreso Nacional de Geología Económica, Buenos Aires. Vol. 2, pp. 149-154.

Godoy, E., Yáñez, G., Vera, E., 1999. Inversion of an Oligocene volcano-tectonic basin and uplift of its superimposed Miocene magmatic arc, Chilean Central Andes: first seismic and gravity evidence. Tectonophysics 306, 217-326.

González Díaz, E.F., 1958. Estructura del basamento y del neopaleozoico en los contrafuertes nord-orientales del Cordón del Portillo, provincia de Mendoza. Rev. Asoc. Geol. Argent. Vol. 12, pp. 98-133.

Gregori, D., Benedini, L., 2013. The cordon del Portillo Permian magmatism, Mendoza, Argentina, plutonic and volcanic sequences at the western margin of Gondwana. J. S. Am. Earth Sci. 42, 61-73.

Gregory-Wodzicki, K., 2000. Uplift history of central and northern Andes: a review. Geol. Soc. Am. Bull. 112 (7), 1091-1105.

Gutscher, M.A., 2002. Andean subduction and their effect on the thermal structure and interpolate coupling. J. S. Am. Earth Sci. 15, 3-10.

Hallam, A., Biró, L., Pérez, E., 1986. Facies analysis of the Lo Valdés Formation (TithonianHauterivian) of High Cordillera central Chile, and the palaeogeographic evolution the Andean basin. Geol. Mag. 123 (4), 425-435.

Hervé, F., Fanning, C.M., Calderón, M., Mpodozis, C.K., 2014. Early Permian to Late Triassic batholiths of the Chilean Frontal Cordillera $\left(28^{\circ}-31^{\circ} \mathrm{S}\right)$ : SHRIMP U-Pb zircon ages and Lu-Hf and O isotope systematics. Lithos 184-187, 436-446.

Hoke, G.D., Graber, N.R., Mescua, J.F., Giambiagi, L.B., Fitzgerald, P.G., Metcalf, J.R., 2015. Near Pure Surface Uplift of the Argentine Frontal Cordillera: insights from (U-Th/ He) thermochronology and geomorphic analysis. In: Sepúlveda, S.A., Giambiagi, L.B., Moreiras, S.M., Pinto, L., Tunik, M., Hoke, G.D., Farías, M. (Eds.), Geodynamic Processes in the Andes of Central Chile and Argentina. Geol. Soc. London, Spec. Publ Vol. 399, pp. 383-399. http://dx.doi.org/10.1144/SP399.4.

Ingersoll, R.V., Bullard, T.F., Ford, R.L., Grimm, J.P., Pickle, J.D., Sares, S.W., 1984. The effect of grain size on detrital modes: a test of the Gazzi-Dickinson point-counting method. J. Sediment. Petrol. 54, 103-116.

Irigoyen, M.V., Villeneuve, M.E., Quigg, F., 1999. Calibration of a Neogene magnetostratigraphy by ${ }^{40} \mathrm{Ar}-{ }^{39} \mathrm{Ar}$ geochronology: the foreland-basin strata of northern Mendoza Province, Argentina. Radiogenic Age and Isotopic Studies: Report 12 Geological Survey of Canada, Current Research, pp. 27-41 (1999-F).

Irigoyen, M.V., Buchan, K.L., Brown, R.L., 2000. Magnetostratigraphy of Neogene Andean foreland basin strata, lat $33^{\circ} \mathrm{S}$, Mendoza Province, Argentina. Geol. Soc. Am. Bull. $112,803-816$

Isacks, B., 1988. Uplift of the Central Andes plateau and bending of the Bolivian Orocline J. Geophys. Res. 93, 3211-3231.

Jordan, T.E., Isacks, B.L., Allmendinger, R.W., Brewer, J.A., Ramos, V.A., Ando, C.J., 1983. Andean tectonics related to geometry of subducted Nazca plate. Geol. Soc. Am. Bull. 94 341-361.

Kleiman, L.E., Japas, M.S., 2009. The Choiyoi volcanic province at $34-36^{\circ} \mathrm{S}$ (San Rafael, Mendoza, Argentina): implications for the late Paleozoic evolution of the southwestern margin of Gondwanana. Tectonophysics 473, 282-299.

Klohn, C., 1960. Geología de La Cordillera de Los Andes de Chile Central, Provincia de Santiago, O'Higgins, Colchagua Y Curicó. Instituto de Investigaciones Geológicas, Boletín. Vol. 8 pp. 1-95.

Koukharsky, M., 1997. Informe petrológico. Hoja 3369-09, Uspallata. Provincia de Mendoza. Servicio Geológico Minero Argentino, Reporte técnico, Buenos Aires. 
Kozlowski, E., Manceda, R., Ramos, V.A., 1993. Estructura. In: Ramos, V.A. (Ed.), Geología Y Recursos Naturales de Mendoza, Asociación Geológica Argentina, XII Congreso Geológico Argentino and II Congreso de Exploración de Hidrocarburos, Buenos Aires. Vol. I (18), pp. 235-256.

Krawinkel, H., Wozazek, S., Krawinkel, J., Hellmann, W., 1999. Heavy-mineral analysis and clinopyroxene geochemistry applied to provenance analysis of lithic sandstones from the Azuero-Sonà complex (NW Panama). Sediment. Geol. 124, 149-168.

Kurtz, A., Kay, S.M., Charrier, R., Farrar, E., 1997. Geochronology of Miocene plutons and exhumation history of the el Teniente region, Central Chile $\left(34^{\circ}-35^{\circ} \mathrm{S}\right)$. Rev. Geol. Chile 24 (1), 75-90

Kutterolf, S., Diener, R., Schacht, U., Krawinkel, H., 2008. Provenance of the carboniferous Hochwipfel formation (Karawanken Mountains, Austria/Slovenia) - geochemistry versus petrography. Sediment. Geol. 203, 246-266.

Lee, Y., 2002. Provenance derived from the geochemistry of late Paleozoic-early Mesozoic mudrocks of the Pyeongan Supergroup, Korea. Sediment. Geol. 149 (4), 219-235.

Legarreta, L., Gulisano, C.A., 1989. Análisis estratigráfico secuencial de la Cuenca Neuquina (Triásico superior-Terciario inferior). In: Chebli, G.A., Spalletti, L.A. (Eds.), Cuencas Sedimentarias ArgentinasInst. Sup. de Corr. Geol. Vol. 6. Universidad Nacional de Tucumán, Serie Correlación Geológica, pp. 221-243.

Linares, E., González, R.R., 1990. Catálogo de edades radiométricas de la República Argentina, 1957-1987. Vol. 19. Publicaciones especiales de la Asociación Geológica Argentina. Serie "B" (Didáctica y complementaria), Buenos Aires (630 p).

Ludwig, K.R., 2003. Isoplot 3.0 - A Geochronological Toolkit for Microsoft Excel: Berkeley Geochronology Center. Vol. 4. Special Publications (71 p).

Ludwig, K.R., 2008. Manual for Isoplot 3.7. Vol. 4. Berkeley Geochronology Center Special Publication (77 p)

Martínez, A., Giambiagi, L., 2010. Evolución petrológica y geoquímica del magmatismo bimodal Permo-Triásico del Grupo Choiyoi en el cordón del Portillo, Mendoza, Argentina. Vol. 30. Trabajos de Geología, Oviedo, pp. 432-451.

Mescua, J.F., Giambiagi, L.B., Bechis, F., 2008. Evidencias de tectónica extensional en el Jurásico tardío (Kimeridgiano) del suroeste de la provincia de Mendoza. Rev. Asoc Geol. Argent. 63 (4), 512-519.

Morton, A.C., Hallsworth, C.R., 1999. Processes controlling the composition of heavy mineral assemblages in sandstones. Sediment. Geol. 124, 3-29.

Muñoz-Sáez, C., Pinto, L., Charrier, R., Nalpas, T., 2014. Influence of depositional load on the development of a shortcut fault system during the inversion of an extensiona basin: the Eocene-Oligocene Abanico Basin case, central Chile Andes $\left(33^{\circ}-35^{\circ} \mathrm{S}\right)$. Andean Geol. 41 (1), 1-28. http://dx.doi.org/10.5027/andgeoV41n1-a01.

Naipauer, M., García Morabito, E., 2012. Intraplate late Jurassic deformation and exhumation in western central Argentina: constraints from surface data and U-Pb detrital zircon ages. Tectonophysics 524-525, 59-75.

Naipauer, M., Tunik, M., Marques, J.C., Rojas Vera, E.A., Vujovich, G.I., Marcio, M., Pimentel, M.M., Ramos, V.A., 2015. Pb detrital zircon ages of Upper Jurassic continental successions: implications for the provenance and absolute age of the Jurassic-Cretaceous boundary in the Neuquén Basin. In: Sepúlveda, S.A., Giambiagi, L.B., Moreiras, S. Pinto, L., Tunik, M., Hoke, G.D., Farías, M. (Eds.), Geodynamic Processes in the Andes of Central Chile and Argentina. Geol. Soc. London, Spec. Publ Vol. 399, pp. 131-154. http://dx.doi.org/10.1144/SP399.1.

Nyström, J.O., Vergara, M., Morata, D., Levi, B., 2003. Tertiary volcanism during extension

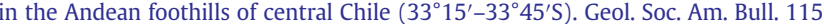
1523-1537.

Oghenekomea, M.E., Chatterjeea, T.K., Hammondb, N.Q., van Bever Donkera, J.M., 2016 Provenance study from petrography of the late Permian - early Triassic sandstones of the Balfour Formation Karoo Supergroup, South Africa. J. Afr. Earth Sci. 114, 125-132. http://dx.doi.org/10.1016/j.jafrearsci.2015.11.002.

Oliveros, V., Labbe, M., Rossel, P., Charrier, R., Encinas, A., 2012. Late Jurassic paleogeographic evolution of the Andean back-arc basin: new constrains from the Lagunillas formation, northern Chile $\left(27^{\circ} 30^{\prime}-28^{\circ} 30^{\prime}\right.$ S). J. S. Am. Earth Sci. 37, 25-40.

Orme, H.M., Atherton, M.P., 1999. New U-Pb and Sr-Nd Data from the Frontal Cordillera Composite Batholith, Mendoza: Implications for Magma Source and Evolution. IV International Symposium on Andean Geology, Goettingen, pp. 555-558.

Paces, J., Miller, J., 1993. Precise U-Pb ages of Duluth complex and related mafic intrusions, northeastern Minnesota; geochronological insights to physical, petrogenetic, paleomagnetic, and tectonomagmatic processes associated with the $1.1 \mathrm{Ga}$ midcontinent rift system. J. Geophys. Res. 98 (B8). http://dx.doi.org/10.1029/93JB01159 0148-0227.

Pángaro, F., Godoy, E., Ramos, V.A., 1996. La faja plegada y corrida de la cordillera principa de Argentina y Chile a la latitud del cerro Palomares $\left(33^{\circ} 35^{\prime} \mathrm{S}\right)$. 2. XIII Congreso Geológico Argentino and III Congreso Exploración de Hidrocarburos, Asociación Geológica Argentina, Mendoza, Argentina, Actas, pp. 315-324.

Pérez, D.J., 2001. El volcanismo neógeno de la cordillera de las Yaretas, cordillera frontal (34으) Mendoza. Rev. Asoc. Geol. Argent. 56 (2), 221-239 (0004-4822).

Pettijohn, F., Potter, P., Siever, R., 1987. Sand and Sandstones. 2nd edition. Springer, Verlag $(553 \mathrm{p})$

Pinto, L., Hérail, G., Moine, B., Fontan, F., Charrier, R., Dupré, B., 2004. Using geochemistry to establish the igneous provenances of the Neogene continental sedimentary rocks in the central depression and Altiplano, Central Andes. Sediment. Geol. $166(1 / 2)$, 157-183.

Pinto, L., Hérail, G., Fontan, F., De Parseval, P., 2007. Neogene erosion and uplift of the western edge of the Andean plateau as determined by detrital heavy mineral analysis. Sediment. Geol. 195, 217-237.

Polanski, J., 1958. El bloque varíscico de la Cordillera Frontal de Mendoza. Rev. Asoc. Geol. Argent. 12 (3), 165-196.

Polanski, J., 1964. Descripción geológica de la Hoja 25 ab - Volcán de San José, provincia de Mendoza. Dirección Nacional de Geología y Minería, Boletín 98, 1-92.

Porras, H., 2013. Registro del levantamiento de la Cordillera de Los Andes durante el Mioceno basado en las características geoquímicas y mineralógicas de los depósitos sintectónicos de la Cuenca del Alto Tunuyán (33³0'S, Argentina) (Master thesis) Departamento de Geología, Universidad de Chile (200 p)

Porras, H., Pinto, L., Tunik, M., 2012. Análisis de proveniencia de minerales pesados detríticos en la cuenca de antepaís del Alto Tunuyán y su implicancia en el alzamiento temprano de la Cordillera Frontal. Vol. 1. XIII Congreso Geológico Chileno, Antofagasta, pp. 628-630.

Ramos, V.A., 1988. The tectonics of the Central Andes, $30^{\circ}-33^{\circ} \mathrm{S}$ latitude. In: Clark, S., Burchfield, D. (Eds.), Processes in Continental Litospheric Deformation. Geol. Soc. Spec. Publ Vol. 218, pp. 31-34.

Ramos, V.A., 2009. Anatomy and global context of the Andes: main geologic features and the Andean orogenic cycle. In: Kay, S.M., Ramos, V.A., Dickinson, W. (Eds.), Backbone of the Americas, Shallow Subduction, Plateau Uplift and Terrane Collision. Geol. Soc. Am Vol. 204, pp. 31-66.

Ramos, V.A., Basei, M., 1997. The Basement of Chilenia: An Exotic Continental Terrane to Gondwana During the Early Paleozoic. Vol. 97. VIII International Terrane Conference, Terrane Dynamics, Christchurch, pp. 140-143.

Ramos, V.A., Cegarra, M.I., Cristallini, E., 1996a. Cenozoic tectonic of the high Andes of West-Central Argentina (30-36 $6^{\circ}$ latitude). Tectonophysics 259, 185-200.

Ramos, V.A., Godoy, E., Godoy, V., Pángaro, F., 1996b. Evolución tectónica de la cordillera principal Argentino-Chilena a la latitud del Paso de Piuquenes $\left(33^{\circ} 30^{\prime} \mathrm{S}\right)$. XIII Congreso Geológico Argentino and III Congreso Exploración de Hidrocarburos, Asociación Geológica Argentina, Buenos Aires, pp. 337-352.

Ramos, V.A., Aguirre-Urreta, M.B., Álvarez, P.P., Colluccia, A., Giambiagi, L., Pérez, D.J., Tunik, M., Vujovich, G.I., 2000. Descripción de la Hoja Geológica Cerro Tupungato, Provincia de Mendoza, 1:250.000. Subsecretaría de Minería de la Nación, Dirección Nacional del Servicio Geológico, Buenos Aires (223 p).

Roser, B., Korsh, R., 1986. Determination of tectonic setting of sandstone-mudstone suites using $\mathrm{SiO}_{2}$ content and $\mathrm{K}_{2} \mathrm{O} / \mathrm{Na}_{2} \mathrm{O}$ ratio. J. Geol. 94 (5), 635-650.

Roser, B.P., Korsch, R.J. 1988. Provenance signatures of sandstone-mudstone suites determined using discriminant function analysis of major-element data. Chem. Geol. 67, 119-139.

Schaltegger, U., Fanning, C.M., Günther, D., Maurin, J.C., Schulmann, K., Gebauer, D., 1999. Growth, annealing and recrystallization of zircon and preservation of monazite in high-grade metamorphism: conventional and in-situ U-Pb isotope, cathodoluminescence and microchemical evidence. Contrib. Mineral. Petrol. 134 (2), 186-201.

Sláma, J., Košler, J., Condon, D.J., Crowley, J.L., Gerdes, A., Hanchar, J.M., Horstwood, M.S.A., Morris, G.A., Nasdala, L., Norberg, N., Schaltegger, U., Schoene, B., Tubrett, M.N., Whitehouse, M.J., 2008. Plešovice zircon - a new natural reference material for U$\mathrm{Pb}$ and $\mathrm{Hf}$ isotopic microanalysis. Chem. Geol. 249 (1-2), 1-35.

Solari, L.A., Gómez-Tuena, A., Bernal, J.P., Pérez-Arvizu, O., Tanner, M., 2010. U-Pb zircon geochronology by an integrated LAICPMS microanalytical workstation: achievements in precision and accuracy. Geostand. Geoanal. Res. 34 (1), 5-18.

Spalletti, L.A., Queralt, I., Matheos, S.D., Colombo, F., Maggi, J., 2008. Sedimentary petrology and geochemistry of siliciclastic rocks from the upper Jurassic Tordillo formation (Neuquén Basin, western Argentina): implications for provenance and tectonic setting. J. S. Am. Earth Sci. 25, 440-463.

Stern, C., 2004. Active Andean volcanism: its geologic and tectonic setting. Rev. Geol. Chile 31 (2), 161-206.

Tapia, F., Naipauer, M., Farías, M., Mescua, J., Pimentel, M.M., Rossel, P., Oliveros, V., Ramos, V.A., 2014. Nuevas edades de U-Pb en circones detríticos del borde occidental de la cuenca neuquina: evidencias de la dinámica del arco del Jurásico Superior. XIX Congreso Geológico Argentino, Córdoba, Argentina (2-6 junio, 2014, Actas S22-64, 2 p).

Tassara, A., Yáñez, G., 2003. Relación entre el espesor elástico de la litósfera y la segmentación tectónica del margen andino (15-47º S). Rev. Geol. Chile 30, 159-186.

Thiele, R., 1980. In: Hoja, Santiago (Ed.), Instituto de Investigaciones Geológicas, Carta Geológica de Chile, N ${ }^{\circ} 39$, Scale 1:100.000 51 p.

Tortosa, A., Palomares, M., Arribas, J., 1991. Quartz grain types in Holocene deposits from the Spanish Central System: some problems in provenance analysis. In: Morton, A.C., Todd, S.P., Haughton, P.D.W. (Eds.), Developments in Sedimentary Provenance Studies. J. Geol. Soc. London, Spec. Publ Vol. 57, pp. 47-54

Troncoso, C., Estudio estratigráfico y de volcanología física de la Ignimbrita Pudahuel (Chile) (Undergraduate thesis), Departamento de Geología, Universidad de Chile $(90 \mathrm{p})$.

Tunik, M., 2003. Interpretación paleoambiental de la Formación Saldeño (Cretácico superior), en la Alta Cordillera de Mendoza, Argentina. Rev. Asoc. Geol. Argent. 58 (3), 417-433.

Vergara, M., Nyström, J.O., 1996. Geochemical features of lower cretaceous back-arc lavas in the Andean Cordillera, Central Chile $\left(31^{\circ}-34^{\circ} \mathrm{S}\right)$. Rev. Geol. Chile 23 (1), 97-106.

Vidal, A., 2007. Petrología y metamorfismo de muy bajo grado en rocas volcánicas del área Laguna Negra - Río Yeso, Cajón del Maipo, Santiago (Undergraduate thesis) Departamento de Geología, Universidad de Chile (190 p).

Weltje, G.J., Von Eynatten, H., 2004. Quantitative provenance analysis of sediments: review and outlook. Sediment. Geol. 171, 1-11.

Willner, A.P., Gerdes, A., Massonne, H.J., 2008. History of crustal growth and recycling at the Pacific convergent margin of South America at latitudes $29-36^{\circ} \mathrm{S}$ revealed by a $\mathrm{U}-\mathrm{Pb}$ and Lu-Hf isotope study of detrital zircon from late Paleozoic accretionary systems. Chem. Geol. 253, 114-129.

Willner, A.P., Gerdes, A., Massonne, H.-J., Schmidt, A., Sudo, M., Thomson, S.N., Vujovich, G., 2011. The geodynamics of collision of a microplate (Chilenia) in Devonian times deduced by the pressure-temperature-time evolution within part of a collisional belt (Guarguaráz Complex, Argentina). Contrib. Mineral. Petrol. 162, 303-327.

Yrigoyen, M.R., 1993. Los depósitos sinorogénicos terciarios. In: Ramos, V.A. (Ed.), Geología y recursos naturales de la Provincia de Mendoza, Mendoza, Argentina. 887, pp. $123-148$

Zuffa, G.G. (Ed.), 1985. Provenance of Arenites. Reidel Publishing Company (408 p). 